\title{
SIRT1 Mediates Depression-Like Behaviors in the Nucleus Accumbens
}

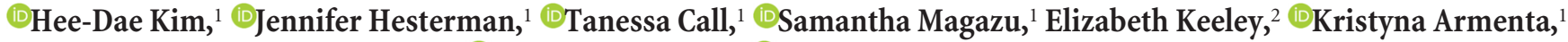 \\ Hope Kronman, ${ }^{2}$ Rachael L. Neve, ${ }^{3}{ }^{\odot E}$ Eric J. Nestler, ${ }^{2}$ and ${ }^{\circ D e v e r o u x ~ F e r g u s o n ~}{ }^{1}$ \\ ${ }^{1}$ Department of Basic Medical Sciences, University of Arizona College of Medicine-Phoenix, Phoenix, Arizona 85004, ${ }^{2}$ Fishberg Department of Neuroscience \\ and Friedman Brain Institute, Icahn School of Medicine at Mount Sinai, New York, New York 10029, and ${ }^{3}$ Department of Brain and Cognitive Sciences, \\ Massachusetts Institute of Technology, Cambridge, Massachusetts 02139
}

Depression is a recurring and life-threatening illness that affects up to 120 million people worldwide. In the present study, we show that chronic social defeat stress, an ethologically validated model of depression in mice, increases SIRT1 levels in the nucleus accumbens $(\mathrm{NAc})$, a key brain reward region. Increases in SIRT 1, a well characterized class III histone deacetylase, after chronic social defeat suggest a role for this enzyme in mediating depression-like behaviors. When resveratrol, a pharmacological activator of SIRT1, was directly infused bilaterally into the NAc, we observed an increase in depression- and anxiety-like behaviors. Conversely, intra-NAc infusions of EX-527, a SIRT1 antagonist, reduced these behaviors; EX-527 also reduced acute stress responses in stress-naive mice. Next, we increased SIRT1 levels directly in NAc by use of viral-mediated gene transfer and observed an increase in depressive- and anxiety-like behaviors when mice were assessed in the open-field, elevated-plus-maze, and forced swim tests. Using a Cre-inducible viral vector system to overexpress SIRT1 selectively in dopamine D1 or D2 subpopulations of medium spiny neurons (MSNs) in the NAc, we found that SIRT1 promotes depressive-like behaviors only when overexpressed in D1 MSNs, with no effect seen in D2 MSNs. Conversely, selective ablation of SIRT1 in the NAc using viral-Cre in floxed Sirt1 mice resulted in decreased depression- and anxiety-like behaviors. Together, these results demonstrate that SIRT1 plays an essential role in the NAc in regulating mood-related behavioral abnormalities and identifies a novel signaling pathway for the development of innovative antidepressants to treat major depressive disorders.

Key words: anxiety; cell-type specific; depression; epigenetic; stress; striatum

\section{Significance Statement}

In this study, we demonstrate a pivotal role for SIRT1 in anxiety- and depression-like behaviors in the nucleus accumbens (NAc), a key brain reward region. We show that stress stably induces SIRT1 expression in this brain region and that altering SIRT1 activity using a pharmacological or genetic approach regulates anxiety- and depression-like behaviors. These results suggest that SIRT1 plays an essential role in regulating mood-related behaviors and introduces a novel signaling pathway for the development of innovative antidepressants to treat depression and other stress-related disorders. A recent groundbreaking publication by the CONVERGE Consortium (2015) identified a reproducible association of the SIRT1 locus with major depression in humans. Therefore, our results are timely and have significant translational relevance.

\section{Introduction}

Major depressive disorder (MDD) is a leading cause of disability worldwide, with $\sim 20 \%$ of individuals suffering from clinical de-

Received Jan. 19, 2016; revised May 23, 2016; accepted June 22, 2016.

Author contributions: D.F. designed research; H.-D.K., J.H., T.C., S.M., E.K., K.A., H.K., and D.F. performed research; R.L.N. and E.J.N. contributed unpublished reagents/analytic tools; H.-D.K. and D.F. analyzed data; H.-D.K., E.J.N., and D.F. wrote the paper.

This work was supported by grants from the National Alliance for Research on Schizophrenia and Depression and the National Institute of Mental Health-National Institutes of Health.

Correspondence should be addressed to Deveroux Ferguson, Department of Basic Medical Sciences, University of Arizona College of Medicine-Phoenix, Phoenix, AZ 85004. E-mail: dferguson@email.arizona.edu.

DOI:10.1523/JNEUROSCI.0212-16.2016

Copyright $\odot 2016$ the authors $\quad 0270-6474 / 16 / 368441-12 \$ 15.00 / 0$ pression during their lifetimes (Krishnan and Nestler, 2011). Depression is a heterogeneous syndrome consisting of several subtypes and abnormalities in multiple brain regions (Nestler et al., 2002). Of significant interest is the development of valid animal models for depression to aid our understanding of the neurobiological and molecular mechanisms underlying this disorder. The chronic social defeat stress procedure in mice is one such validated model of depression and other stress-related disorders, which induces physiological and behavioral changes that recapitulate depression- and anxiety-like symptomatology (Berton et al., 2006; Tsankova et al., 2006; Krishnan et al., 2007) and alter gene expression programs in the nucleus accumbens (NAc; Berton et al., 2006; Krishnan et al., 2007; Wilkinson et al., 2009; 
Bagot et al., 2016), a key brain reward region (Nestler et al., 2002; Sesack and Grace, 2010). The NAc is most often associated with the rewarding and motivational effects of food, sex, and drugs of abuse (Nestler et al., 2002). Given the prominence of anhedonia, reduced motivation, and decreased energy levels in most individuals with depression, the NAc is thought to contribute importantly to the symptomatology of the syndrome (Tremblay et al., 2005; Krishnan and Nestler, 2008; Covington et al., 2010).

A recent groundbreaking human genetics study revealed Sirt1 as one of the first two genes successfully linked to MDD in a genome-wide investigation (CONVERGE Consortium, 2015). SIRT1, a member of the sirtuin family, is characterized as a class III histone deacetylase (HDAC), which regulates the acetylation state of histones and nonhistone proteins (Vaquero et al., 2007) and thereby influences gene expression and cellular physiology (Sassone-Corsi, 2012). SIRT1 has been implicated in a range of physiological processes, including cell differentiation, apoptosis, autophagy, development, cancer metabolism, and circadian rhythms (Yang et al., 2007; Kwon and Ott, 2008; Lee et al., 2008; Nakahata et al., 2009; Ramadori and Coppari, 2011; Ramadori et al., 2011; Tonkin et al., 2012). Recent data from our group and others have begun to elucidate a novel role for SIRT1 in higherorder brain functions such as drug addiction (Renthal et al., 2009; Ferguson et al., 2013; Ferguson et al., 2015), circadian rhythmicity (Asher et al., 2008; Chang and Guarente, 2013), endocrine regulation (Cohen et al., 2009; Ramadori et al., 2011), and synaptic plasticity (Gao et al., 2010; Michán et al., 2010).

In the present study, using both pharmacological and viralvector-transgenic approaches, we demonstrate that chronic social defeat stress induces SIRT1 expression in the NAc and that SIRT1 induction in this region promotes depression- and anxiety-like behaviors. These findings suggest an important role for SIRT1 acting in the NAc in regulating mood disorders and present a novel path forward for the development of a new class of antidepressants targeting the sirtuin-signaling pathway.

\section{Materials and Methods}

Animals. Male C57BL/6J mice (7-9 weeks old) were obtained from The Jackson Laboratory and housed on a $12 \mathrm{~h}$ light/dark cycle with ad libitum access to food and water. Male CD1 retired breeder mice (9-13 months old) were obtained from Charles River Laboratories. Mice acclimated to the facility for 1 week before any experimentation. D1-Cre hemizygote (line FK150) or D2-Cre hemizygote (line ER44) BAC transgenic mice from GENSAT (Gong et al., 2007; Gerfen et al., 2013) on a C57BL/6J background were used for some behavioral experiments. To induce deletion of the Sirt1 transcript in the NAc, we used mutant mice homozygous for a floxed Sirt1 allele, which are fully backcrossed onto C57BL/6J and have been described in detail previously (Li et al., 2007). Mice between the ages of 8 and 10 weeks were injected sterotaxically into the NAc with any of several viral vectors (see below). All animal procedures were approved by the Mount Sinai School of Medicine and the University of Arizona Medical School Institutional Animal Care and Use Committees.

Chronic social defeat stress. Social defeat stress was performed according to previously published protocols (Krishnan et al., 2007). Test mice were exposed to an unfamiliar and aggressive male CD1 retired breeder mouse for $10 \mathrm{~min} / \mathrm{d}$ for up to $10 \mathrm{~d}$. After direct interaction with the CD1 aggressor, animals were placed in an adjacent compartment of the same cage for the next $24 \mathrm{~h}$ with sensory, but not physical, contact. Control animals were housed in equivalent cages but with members of the same strain. Twenty-four hours after the last social defeat, animals were assayed on the social interaction test and sorted into either susceptible or unsusceptible (resilient) phenotypes based on interaction scores (Krishnan et al., 2007). Briefly, for the social interaction test in the first $2.5 \mathrm{~min}$ trial ("target absent"), the test mouse was allowed to explore freely a square-shaped open-field arena $(44 \times 44 \mathrm{~cm})$ possessing an empty wire- mesh cage $(10 \times 6 \mathrm{~cm})$ apposed to one side. During the second $2.5 \mathrm{~min}$ trial ("target present"), the mouse was reintroduced into this arena now containing an unfamiliar CD1 mouse within the smaller cage. EthoVision video-tracking software (Noldus) was used to measure time spent in the "interaction zone" $(14 \times 26 \mathrm{~cm})$. In some experiments, we used a submaximal social defeat procedure in which mice were subjected to repeated defeat episodes over $1 \mathrm{~d}$. Animals were placed into the CD1 aggressor's cage for $5 \mathrm{~min}$, followed by a $15 \mathrm{~min}$ break. This was repeated two further times with different CD1 aggressors. This submaximal defeat procedure has been used by our group to test whether an experimental manipulation might potentiate an animal's susceptibility to defeat stress (Krishnan et al., 2007).

Open-field test. Open-field assessments, which are thought to reflect anxiety-related behavior, were conducted in arenas similar to those used for the social interaction tests (without small cage enclosures). Etho Vision video-tracking-based methods (Noldus) were used to record the distance traveled and the time spent in the open arena and a delineated "center zone."

Elevated-plus maze test. The elevated-plus maze test, an assay of anxiety-like behavior, consisted of two opposite open arms $(60 \times 15 \mathrm{~cm})$ and two enclosed arms $(60 \times 15 \mathrm{~cm}$, surrounded by a $15 \mathrm{~cm}$-high black wall) elevated $75 \mathrm{~cm}$ from the ground. Animals were placed at the center of the maze for each individual trial lasting $5 \mathrm{~min}$. The number of entries and the time spent in open arms were measured, in addition to the number of entries in enclosed arms.

Forced swim test. The forced swim test, which measures acute stress responses, was performed as described previously (Krishnan et al., 2007). Animals were placed in a $4 \mathrm{~L}$ beaker containing $3 \mathrm{~L}$ of water at a temperature of $25 \pm 1{ }^{\circ} \mathrm{C}$. Tracking was performed with EthoVision for a period of $5 \mathrm{~min}$. The experiment was performed under red light. Animals were analyzed for the amount of time spent mobile versus immobile.

Sucrose preference test. To assess natural reward using the sucrose preference test, $50 \mathrm{ml}$ tubes containing stoppers fitted with ballpoint sipper tubes were filled with solutions containing either $1 \%$ sucrose diluted in drinking water or drinking water alone. The weights of solutions were recorded and the position of the tubes was interchanged daily to eliminate side bias. Sucrose preference was calculated as a percentage of sucrose intake over total fluid volume consumed and averaged over $3 \mathrm{~d}$ of testing.

Immunoblotting. Immunoblotting was performed using standard procedures on NAc punch dissections from individual animals (Ferguson et al., 2013). Briefly, frozen NAc tissue was homogenized in $30 \mu \mathrm{l}$ of homogenization buffer containing $320 \mathrm{mM}$ sucrose, 5 mM HEPES buffer, $1 \%$ SDS, phosphatase inhibitor cocktails I and II (Sigma-Aldrich), and protease inhibitors (Roche) with an ultrasonic processor (Cole Parmer). Next, $10-30 \mu \mathrm{g}$ of protein as loaded onto $4-15 \%$ gradient Tris- $\mathrm{HCl}$ polyacrylamide gels for electrophoresis fractionation (Bio-Rad). Proteins were transferred to nitrocellulose membranes, blocked with 5\% $(\mathrm{w} / \mathrm{v}) \mathrm{BSA}$, and incubated overnight at $4^{\circ} \mathrm{C}$ with primary antibodies in $5 \%$ BSA. After thorough washing with TBS plus $0.1 \%$ Tween 20 , membranes were incubated with secondary antibodies $(1: 40,000-1: 60,000)$ dissolved in 5\% BSA blocking buffer for $1 \mathrm{~h}$ at room temperature. Final blots were developed by chemiluminescence analysis using supersignal dura ECL (Pierce Biotechnology). Images were quantified using densitometry with ImageJ and samples were normalized using GAPDH or $\beta$-tubulin, which were not affected by social defeat stress.

Immunohistochemistry. Mice were given a lethal dose of Euthasol (Virbac) and then perfused sequentially with PBS and 4\% paraformaldehyde. Brains were postfixed in $4 \%$ paraformaldehyde overnight and cryoprotected in $30 \%$ sucrose solution at $4^{\circ} \mathrm{C}$. After equilibration in the sucrose solution, brains were sectioned at $30 \mu \mathrm{m}$ on a sliding block microtome (American Optical). Free-floating sections were washed with PBS and then blocked (3\% donkey serum, $0.1 \%$ Triton X-100 in PBS). The primary antibody anti-SIRT1 (rabbit polyclonal, 1:500; Cell Signaling Technology) was applied overnight at $4^{\circ} \mathrm{C}$ with constant agitation. After the overnight incubation, sections were incubated with the appropriate secondary antibodies conjugated with fluorescent dyes (Alexa Fluor 488, Alexa Fluor 555, and Cy5; Invitrogen) for $2 \mathrm{~h}$ at room temperature. Next, the sections were washed, mounted with Vectashield 
containing DAPI (Vector Laboratories), and analyzed using confocal microscopy at various magnifications (LSM710; Carl Zeiss).

SIRT1 activity assay. SIRT1 enzymatic activity was measured using a fluorescent assay kit (Cayman) according to the manufacturer's instructions. Briefly, tissue samples were sonicated in RIPA buffer $(0.7 \% \mathrm{Na}-$ deoxycholate, $0.5 \mathrm{~m} \mathrm{LiCl}, 50 \mathrm{~mm}$ HEPES-KOH, pH 7.6, 1\% NP-40, 1 mм EDTA $)$ and $5 \mu \mathrm{l}(1 \mu \mathrm{g} / \mu \mathrm{l})$ of lysates were mixed with assay buffer $(30 \mu \mathrm{l})$ and substrate $(15 \mu \mathrm{l})$ and incubated for $45 \mathrm{~min}$ at room temperature with shaking. Then, developing solution $(50 \mu \mathrm{l})$ was added and incubated for $30 \mathrm{~min}$. Fluorescence was measured with a microplate reader (excitation: $360 \mathrm{~nm}$, emission: $465 \mathrm{~nm}$; SaFire 2, Tecan).

Viral-mediated gene transfer. Mice were anesthetized with a ketamine/ xylazine mixture (ketamine $100 \mathrm{mg} / \mathrm{kg}$ and xylazine $10 \mathrm{mg} / \mathrm{kg}$ ) and prepared for stereotaxic surgery. Thirty-three-gauge syringe needles (Hamilton) were used to infuse $0.5 \mu \mathrm{l}$ of virus bilaterally into NAc at a $10^{\circ}$ angle at a rate of $0.1 \mu \mathrm{l} / \mathrm{min}$ at $1.6 \mathrm{~mm}$ anteroposterior, $1.5 \mathrm{~mm}$ lateral, and $4.4 \mathrm{~mm}$ dorsoventral from bregma. We used bicistronic p1005 HSV (herpes simplex virus) vectors expressing green fluorescent protein (GFP) alone or GFP plus the target gene of interest. In this system, GFP expression is driven by a cytomegalovirus promoter, whereas the gene of interest is driven by the IE4/5 promoter (Ferguson et al., 2013). In some experiments, we used HSV vectors that express their transgene in a Credependent manner (Grueter et al., 2013; Dias et al., 2014). We also used adeno-associated virus (AAV) vectors (serotype 2) expressing GFP or Cre-GFP (Berton et al., 2006). Animals receiving viral injections were allowed to recover for at least $3 \mathrm{~d}$ after HSV delivery or 2 weeks after AAV delivery. Viral injection sites were verified by confirming the GFP signal in the NAc slices using a fluorescence-dissecting microscope.

RNA isolation and PCR. Bilateral 14-gauge punch dissections of NAc, hippocampus, and medial prefrontal cortex were obtained from 1-mmthick coronal brain sections and frozen immediately on dry ice. Dissections were thawed and processed in TRIzol (Invitrogen) according to the manufacturer's guidelines. RNA was isolated and purified using RNeasy Micro columns (QIAGEN). We confirmed the purity of our samples by spectroscopy at 260/280 and 260/230 1.8. RNA was reverse transcribed to cDNA using iScript Kit (Bio-Rad). cDNA was quantified by qPCR using SYBR green. qPCR was performed using an Applied Biosystems 7500 system. Reactions were run in triplicate and analyzed using the Delta Delta Ct method (Livak and Schmittgen, 2001) with GAPDH as a normalization control, which was not affected by social defeat stress.

ChIP. ChIP was performed as described previously (Ferguson et al., $2015)$ with minor modifications. Briefly, for each ChIP, anterior and posterior bilateral 14-gauge NAc punches were pooled (5 animals, 20 NAc punches per sample). Punches were fixed for $10 \mathrm{~min}$ with $1 \%$ formaldehyde and then quenched with $2 \mathrm{M}$ glycine for $5 \mathrm{~min}$. Samples were homogenized using a desktop sonicator at low settings (amplitude 40\%) 2 times for $7 \mathrm{~s}$ on ice. Next, samples were sheered using a Diogenode Bioruptor XL at $4^{\circ} \mathrm{C}$ at high sonication intensity for $30 \mathrm{~s} \mathrm{on} / 30 \mathrm{~s}$ off for 15 $\mathrm{min}$, followed by $5 \mathrm{~min}$ of rest and an additional $10 \mathrm{~min}$ of sonication. Fragment size range of 250-1000 bp was verified with an Agilent bioanalyzer. Before sonication of samples, magnetic sheep anti-rabbit or anti-mouse beads (Invitrogen) were prepared with the respective antibody of interest at $4^{\circ} \mathrm{C}$ overnight on a rotator. After washing of the magnetic bead/antibody complex, $7.5 \mathrm{mg}$ was added to $400 \mu \mathrm{l}$ of sheared chromatin for histone ChIP for $16 \mathrm{~h}$ at $4^{\circ} \mathrm{C}(\mathrm{H} 3 \mathrm{~K} 4 \mathrm{me} 3, \mathrm{H} 3 \mathrm{~K} 9 \mathrm{me} 2$, and $\mathrm{H} 3 \mathrm{~K} 9 \mathrm{me} 3$ ); a normal IgG control was performed to test for nonspecific binding; $80 \mu \mathrm{l}$ of each sample of sheared chromatin was used as input controls. Samples were washed with RIPA and Tris-EDTA buffers. Reverse cross-linking was performed at $65^{\circ} \mathrm{C}$ overnight and proteins were removed with proteinase $\mathrm{K}$ (Invitrogen). DNA was purified using a DNA purification kit (QIAGEN). qPCR analysis for ChIP was performed using an Applied Biosystems 7500 system. Data were normalized with input controls and Gapdh values.

Osmotic minipump infusions. Surgery was performed as described previously (Covington et al., 2009). Briefly, animals were anesthetized with a combination of ketamine $(100 \mathrm{mg} / \mathrm{kg})$ and xylazine $(10 \mathrm{mg} / \mathrm{kg})$ and surgically implanted with two subcutaneous Alzet minipumps (model 1002; Durect) and guide cannulae (Plastics One) targeting the NAc bilaterally. One day before surgery, cannulae (28 gauge stainless steel) were filled with resveratrol (0.1 or $0.2 \mu \mathrm{g} / \mathrm{d})$, EX-527 (0.5 or $1.0 \mu \mathrm{g} / \mathrm{d}$ ), or $0.4 \%$ dimethyl sulfoxide (i.e., vehicle) and each pedestal within the assembly was affixed separately via vinyl tubing to a minipump, each loaded with drug or vehicle. The minipumps were activated on the evening before surgery (by incubating them in sterile saline at $37^{\circ} \mathrm{C}$ ) to initiate a continuous delivery at $0.25 \mu \mathrm{l} / \mathrm{h}$ over $14 \mathrm{~d}$. On the day of surgery, the pumps were implanted in the backs of the mice through small incisions at the base of the neck. Cannulae targeting the NAc according to bregma (anteroposterior, 1.5; mediolateral, 1.0; dorsoventral, $4.5 \mathrm{~mm}$ ) were permanently fixed to the skull with Loctite skull adhesive (Henkel). The coordinates used for minipump surgeries were slightly different from those used for viral vector infusions to account for the hardware that is attached to the skull in the former. Cannulae, tubing, and minipumps were all secured under the skin using Vetbond tissue adhesive $(3 \mathrm{M})$ and two staples. Mice were carefully monitored after the surgery. All behavioral tests were conducted after a $14 \mathrm{~d}$ infusion of each drug.

Cannulation surgery. To assess the effects of resveratrol or EX-527 (0.5 $\mathrm{mm}$ ) on social-stress-induced changes in anxiety and despair-like behaviors, we implanted bilateral cannulae (anteroposterior, 1.5; mediolateral, 1.0; dorsoventral, $4.5 \mathrm{~mm}$ ) targeting the NAc of susceptible mice. One week after surgery, mice were infused with drug or vehicle $30 \mathrm{~min}$ before social interaction behavior, open-field, and elevated-plus maze tests.

Statistical analysis. One-way ANOVAs were performed to determine significance for conditions in which there were more than two groups or two factors. Unpaired Student's $t$ test with a two-tailed $p$-value were used for other comparisons including qPCR and Western blotting. Statistical analysis was performed using Prism 5.0 (GraphPad). All values included in the figure legends represent means \pm SEM.

\section{Results \\ Chronic social defeat stress induces SIRT1 expression in the NAc}

As a first step in studying the role of SIRT1 in depression- and anxiety-like behaviors, we subjected $\mathrm{C} 57 \mathrm{BL} / 6 \mathrm{~J}$ male mice to chronic social defeat stress. The mice were classified as susceptible or resilient based on their social interaction time (Fig. 1A-C), a highly reliable indicator of depressive-like behaviors (Krishnan et al., 2007). Next, using real-time PCR, we measured Sirt1 mRNA expression either $48 \mathrm{~h}$ or $10 \mathrm{~d}$ after the last defeat episode in several brain regions implicated in depression and anxiety, including the NAc, hippocampus, and medial prefrontal cortex (mPFC; Nestler et al., 2002; Holmes and Wellman, 2009). We observed that chronic social defeat stress induces Sirt1 mRNA levels in the NAc of susceptible mice $48 \mathrm{~h}$ after the last social defeat $\left(F_{(2,19)}=9.75, p=0.001\right)$, with no changes seen in resilient mice (Fig. $1 D$ ), and decreases Sirt1 expression in the hippocampus of susceptible mice (Fig. $1 D ; F_{(2,21)}=6.33, p=0.007$ ), with no changes seen in $\mathrm{mPFC}$. In addition, when mRNA was assessed $10 \mathrm{~d}$ after social defeat, we observed persistent elevation of Sirt1 expression in the NAc of susceptible mice $\left(F_{(2,15)}=5.99, p=\right.$ $0.01)$ and elevation in the $\mathrm{mPFC}$ of resilient mice $\left(F_{(2,21)}=21.89\right.$, $p=0.001$; Fig. $1 E$ ), suggesting stable changes in Sirt1 transcriptional regulation in these two brain regions. In contrast, we did not observe an increase in Sirt1 mRNA levels in the NAc after submaximal defeat (Fig. $1 F$ ), indicating the need for chronic stress for induction of Sirt1. We also did not observe changes in the expression of other sirtuin family members (Sirt2-7) in the NAc after chronic social defeat stress. The induction of Sirt1 mRNA in the NAc at the $48 \mathrm{~h}$ time point was paralleled by increased SIRT1 protein expression in this brain region of susceptible mice (Fig. $1 G ; F_{(2,15)}=4.13, p=0.03$ ), with no differences observed in resilient mice. We further investigated histone modifications at the Sirt1 promoter to reveal the mechanism of elevated expression of Sirt1 using ChIP assays in the NAc (Fig. $1 J-O)$. We observed a significant increase of a transcriptionally 


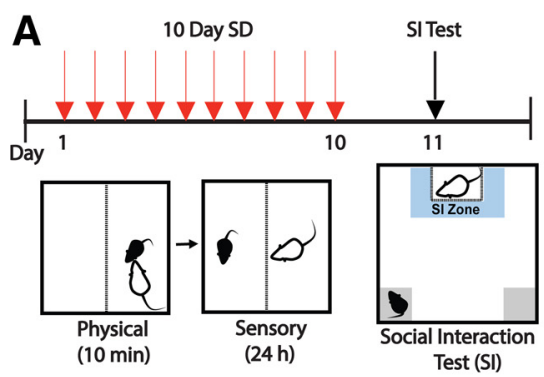

B

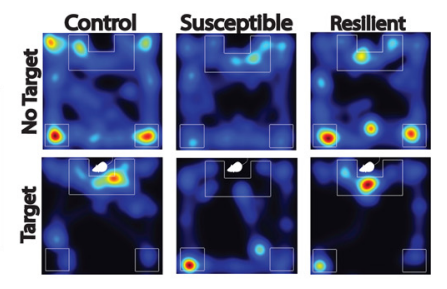

E

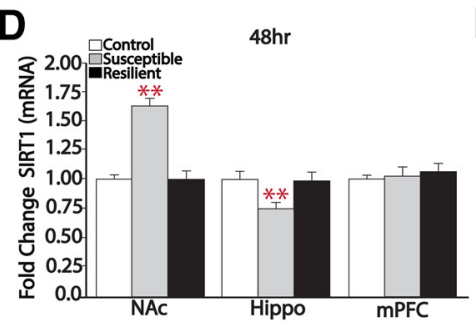

G

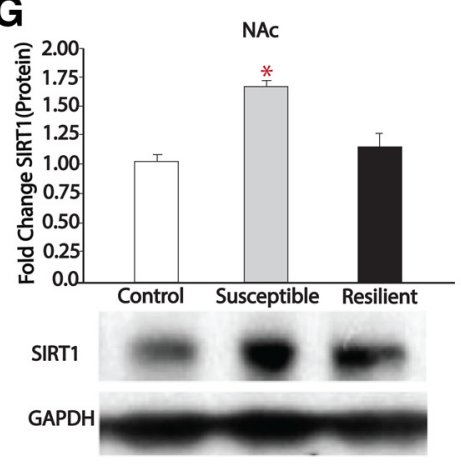

$\mathbf{H}$

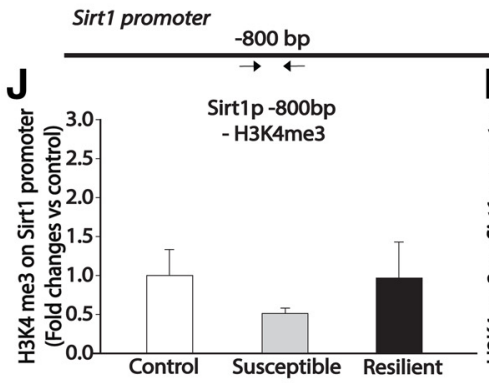

$\mathbf{L}$
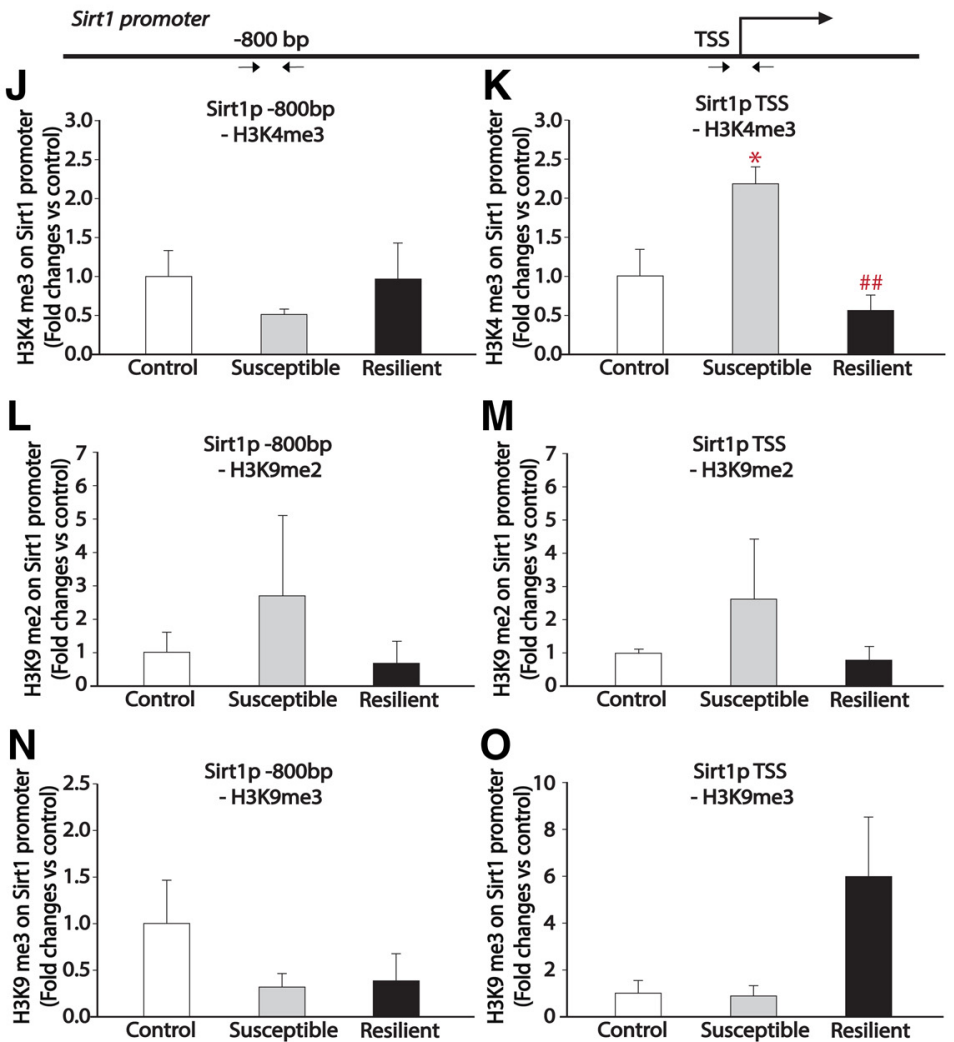
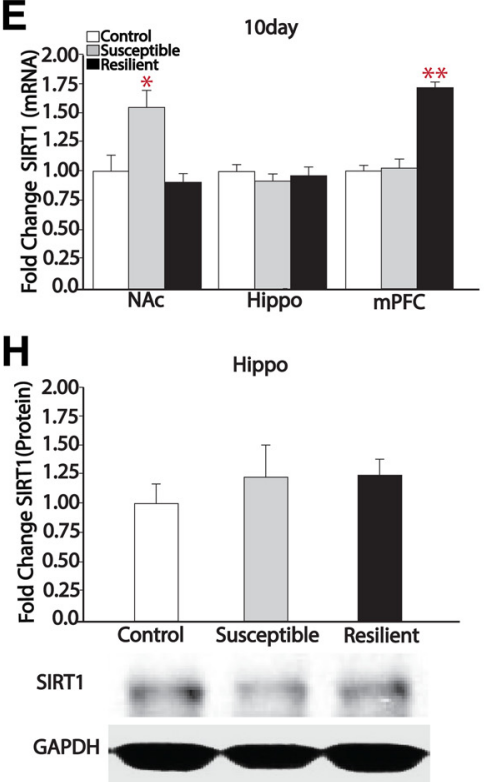

H $\quad$ Hippo
I $\mathrm{mPFC}$

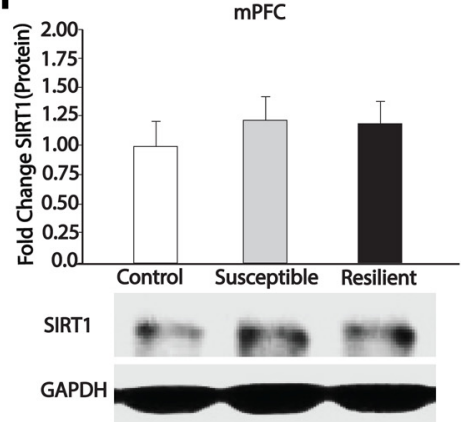

$\mathbf{F}$

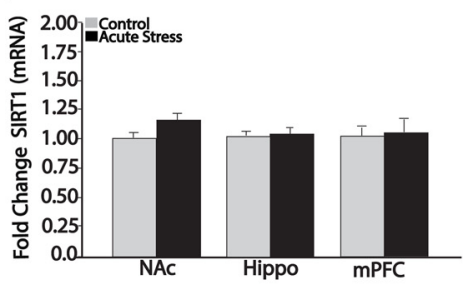

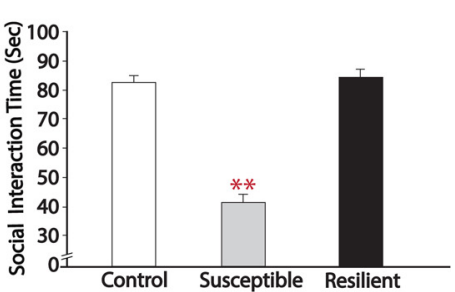

$\backsim$ Control Susceptible Resilient

Figure 1. Chronic social defeat stress induces SIRT1 expression in the NAc. A, Schematic of social defeat (SD) and social interaction (SI) test. Mice were subjected to SD stress for $10 \mathrm{~d}$. On day 11 , mice were tested on SI and classified into susceptible and resilient social defeat subgroups. $\boldsymbol{B}$, Heat map of SI test and representative data for control, susceptible, and resilient mice. $\boldsymbol{C}$, SI data showing decreased social interaction in susceptible but not resilient mice $(n=10-12) . \mathbf{D}, \mathrm{qPCR}$ analysis $48 \mathrm{~h}$ after SD reveals increased levels of Sirt1 mRNA in the NAc (Figure legend continues.) 

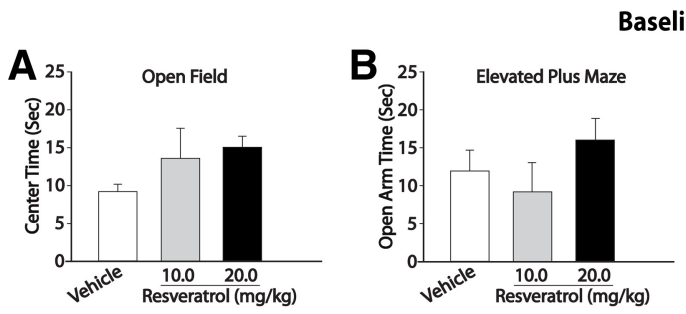

Baseline Behavior
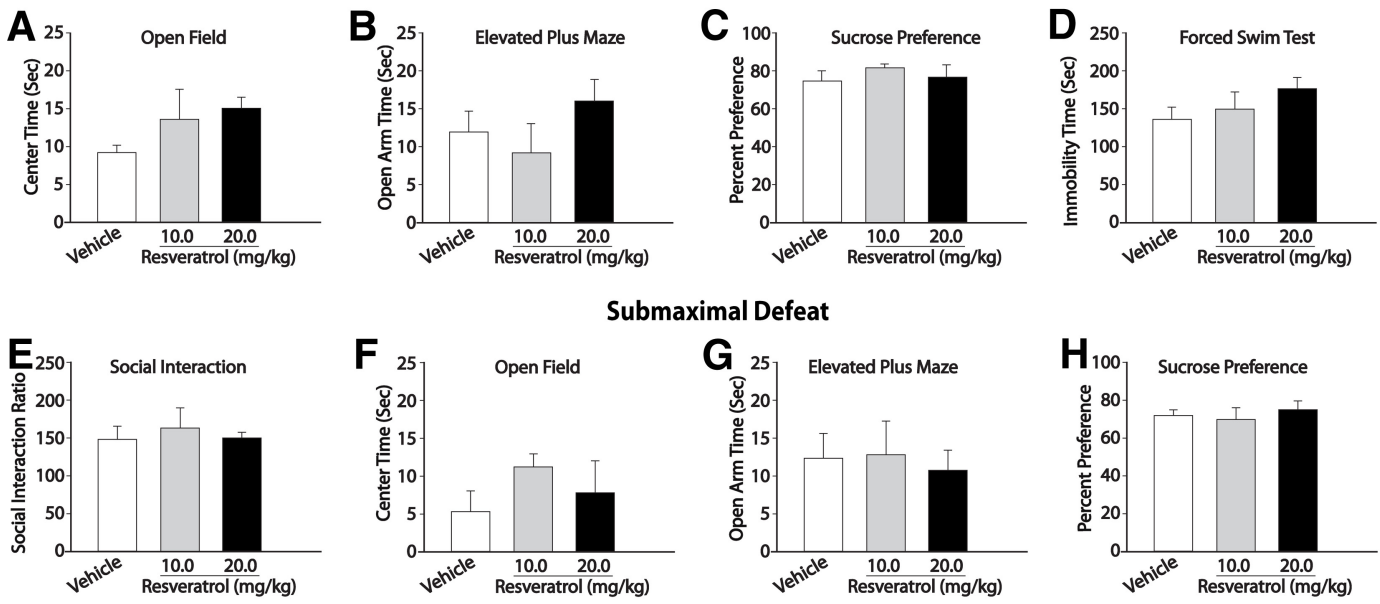

Submaximal Defeat
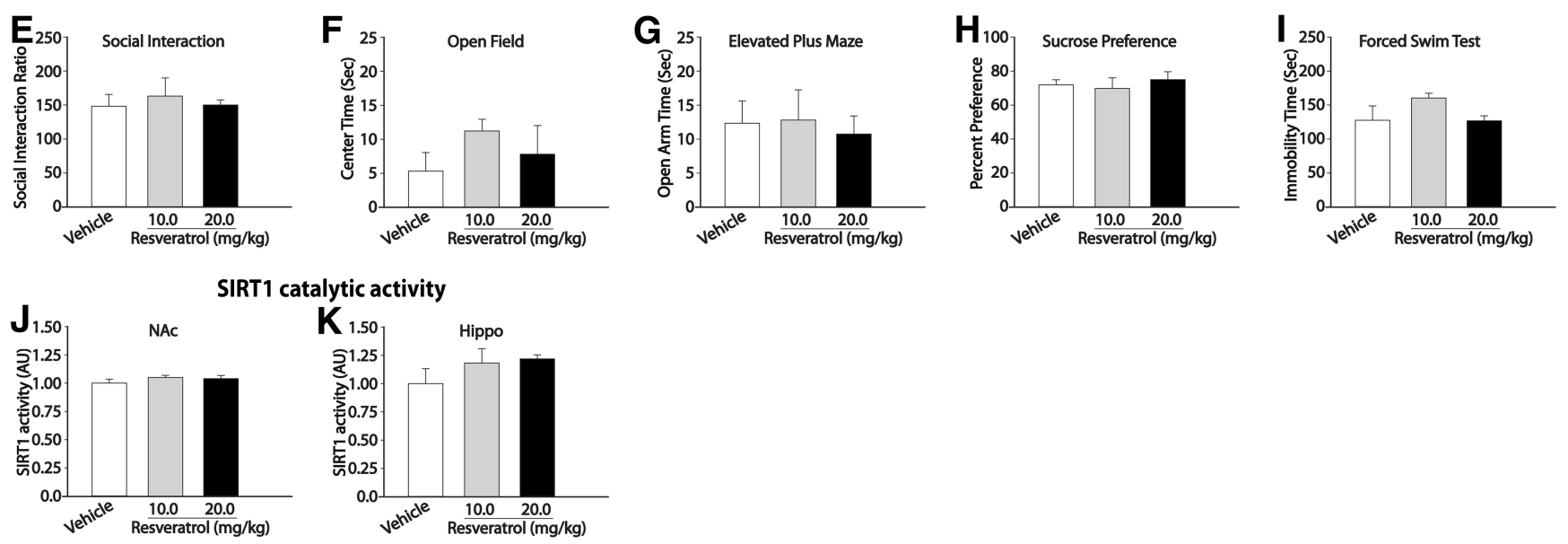

Figure 2. Systemic injection of resveratrol does not change anxiety and depression-like behavior. $\boldsymbol{A}-\boldsymbol{D}$, Systemic injection of the sirtuin activator resveratrol for $14 \mathrm{~d}(10 \mathrm{or} 20 \mathrm{mg} / \mathrm{kg}$, i.p.) does not change baseline behavior on the open-field $(\boldsymbol{A})$, elevated-plus maze $(\boldsymbol{B})$, sucrose preference $(\boldsymbol{C})$, or forced swim tests $(\boldsymbol{D})(\boldsymbol{n}=5)$. $\boldsymbol{E}-\boldsymbol{I}$, Submaximal defeat does not change the behavioral outcomes and social interactions between groups $(n=5) . \boldsymbol{J}, \boldsymbol{K}$, Sirt1 deacetylase activity was measured in the NAc $(\boldsymbol{J})$ and hippocampus $(\boldsymbol{K})$ tissues from baseline groups $(n=5)$. Data are represented as the mean \pm SEM.

active histone modification, trimethylated lysine 4 of histone $\mathrm{H} 3$ (H3K4me3), at the transcription start site (TSS) of the Sirt1 promoter in susceptible mice, but not in the resilient group (Fig. $1 K$; $F_{(2,6)}=10.66, p=0.011$ ). Repressive histone markers (dimethylated and trimethylated lysine 9 of $\mathrm{H} 3$; $\mathrm{H} 3 \mathrm{~K} 9 \mathrm{me} 2$ and $\mathrm{H} 3 \mathrm{~K} 9 \mathrm{me} 3$ ) were not changed significantly at Sirt1 promoter regions among the control, susceptible, and resilient groups (Fig. $1 L-O)$. Together, these data demonstrate that exposure to chronic stress causes the prolonged induction of SIRT1 in the NAc of susceptible mice only.

Pharmacological activation of sirtuins increases depressionand anxiety-like behaviors

We next investigated whether pharmacological activation of sirtuins by resveratrol, a well characterized albeit nonspecific sirtuin activator (Sinclair and Guarente, 2014), alters depressionand anxiety-like behavior. Mice were tested on the open-field, elevated-plus maze, sucrose preference, and forced swim tests. Resveratrol was given as daily intraperitoneal injections for $14 \mathrm{~d}$ at 10 or $20 \mathrm{mg} / \mathrm{kg}$. We did not observe changes in any of these

$\leftarrow$

(Figure legend continued.) $\quad(n=7-8)$ and decreased levels in hippocampus (Hippo; $n=8)$ of susceptible mice, with no changes in the mPFC. $\boldsymbol{E}$, Persistent elevations of Sirt1 mRNA levels in the NAc $(n=6) 10 \mathrm{~d}$ after SD and increases in the $\operatorname{mPFC}(n=8)$ without changes in the Hippo. $\boldsymbol{F}$, Acute submaximal defeat stress does not alter Sirt $1 \mathrm{mRNA}$ levels in the NAc. G-I, Western blot analysis reveals increased SIRT1 protein in the NAc $48 \mathrm{~h}$ after SD $(\boldsymbol{G})$, but not in the Hippo $(\boldsymbol{H})$, and $\mathrm{mPFC}(I)(n=6-8) . \mathbf{J}-\mathbf{0}$, ChIP assay revealing increased gene activation markers (H3K4me3; $n=3$ ) on the (K) TSS of Sirt1 promoter in susceptible mice, but not on the upstream promoter region $(\boldsymbol{J})$, whereas there are no changes between groups in repressive markers (H3K9me2 and H3K9me3; $n=3$ ). ${ }^{*} p<0.05,{ }^{* *} p<0.01$ compared with control group; \#\#p $<$ 0.01 compared with susceptible group. Data are represented as the mean \pm SEM. behaviors after systemic injection of resveratrol (Fig. 2A-D). In addition, systemic resveratrol administration had no effect on the susceptibility of mice exposed to submaximal defeat stress (Fig. 2E-I). When we assessed Sirt 1 activity in the NAc and hippocampus of baseline groups after behavioral tests, no significant changes were detected in any of the groups (Fig. $2 \mathrm{~J}, \mathrm{~K}$ ). However, when resveratrol was infused directly into the NAc bilaterally via osmotic minipumps for $14 \mathrm{~d}$, we observed an increase in depression- and anxiety-like behaviors (Fig. $3 B-D$ ) without detectable changes in exploratory behaviors (Fig. $3 E-H$ ). Figure $3 A$ illustrates intra-NAc infusion timeline, validation of cannula placement, and the SIRT1 activity assay showing increased SIRT1 deacetylase activity in the NAc tissue infused locally with either low $(0.1 \mu \mathrm{g} / \mathrm{d})$ or high $\left(0.2 \mu \mathrm{g} / \mathrm{d} ; F_{(2,18)}=111.4, p<0.001\right)$ doses of resveratrol. Resveratrol infusions $(0.2 \mu \mathrm{g} / \mathrm{d})$ into the NAc decreased time spent in the center of the open field (Fig. $3 B ; F_{(2,23)}=$ $6.93, p=0.004)$ and on the open arm of the elevated-plus maze (Fig. $3 C ; F_{(2,22)}=4.41, p=0.02$ ). In addition, intra-NAc resveratrol decreased sucrose preference (Fig. $3 D ; F_{(2,17)}=3.64, p=$ 0.04). Together, these findings suggest that elevated SIRT1 activity in the NAc increases depression- and anxiety-like behaviors.

\section{Pharmacological inhibition of SIRT1 in the NAc decreases depression- and anxiety-like behaviors}

Next, we investigated whether pharmacological blockade of SIRT1 signaling via a SIRT1-specific inhibitor, EX-527, produces antidepressant and anxiolytic effects in several behavioral assays. EX-527 was infused bilaterally into the NAc via osmotic minipumps at a dose of 0.5 or $1.0 \mu \mathrm{g} / \mathrm{d}$ for $14 \mathrm{~d}$ (Fig. $3 I-K$ ). Such EX-527 infusions decreased SIRT1 deacetylase activity in this brain region $\left(F_{(2,15)}=11.78, p<0.001\right)$, but did not elicit alter- 
A
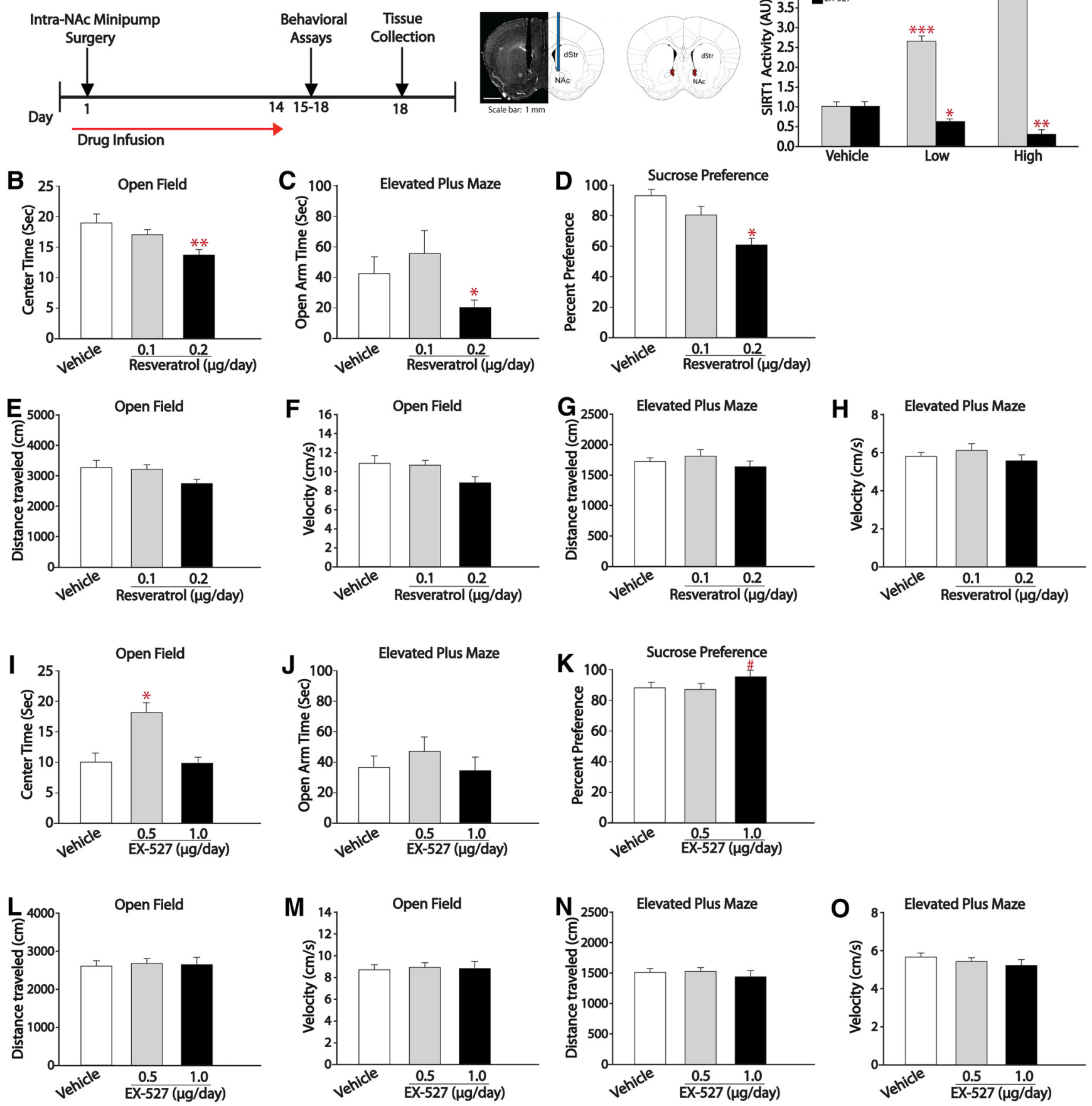

P
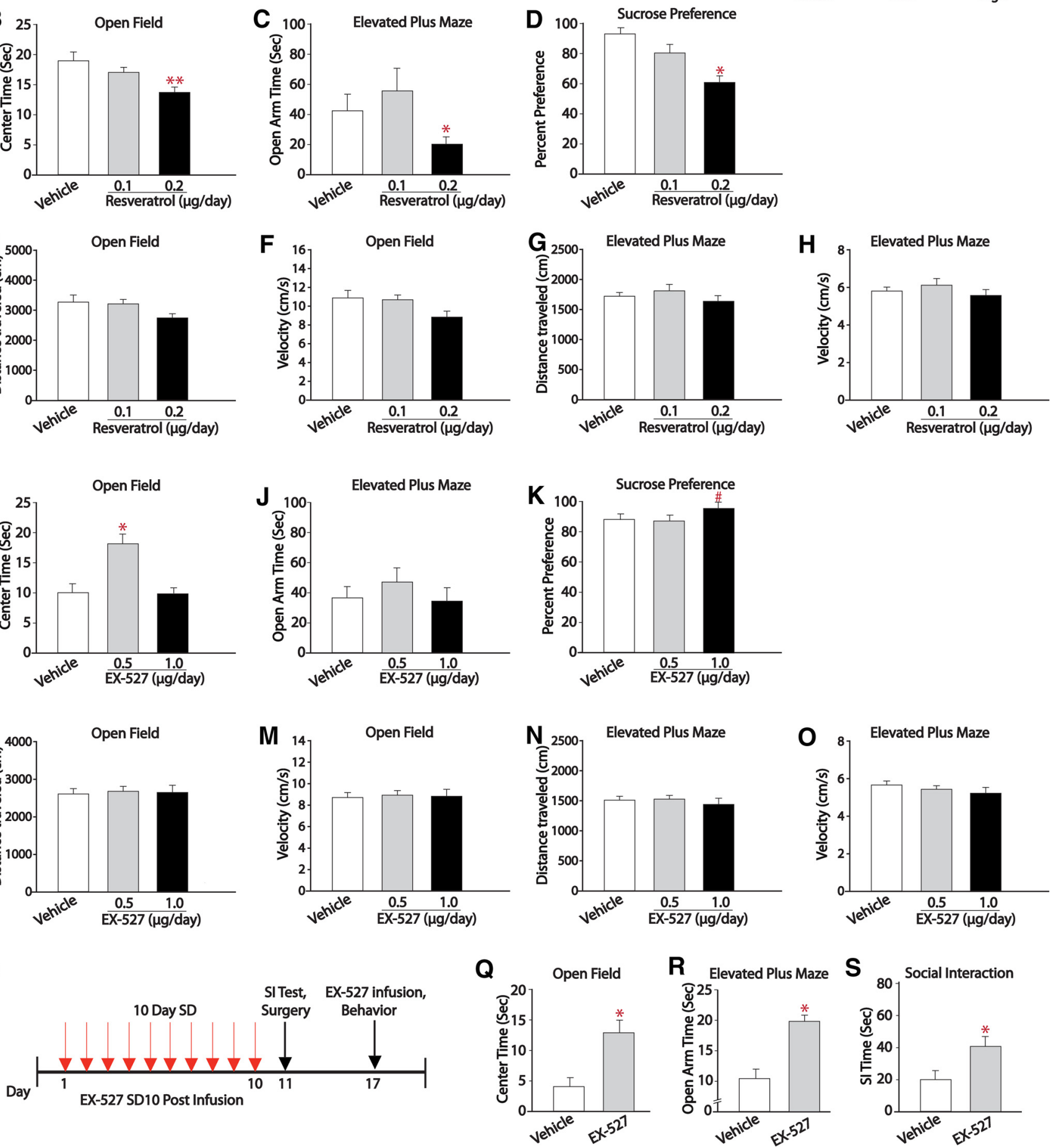

Figure 3. Pharmacological modulation of SIRT1 activity in the NAc regulates anxiety and depression-like behavior bidirectionally. $A$, Schematic of experimental design. Mice were implanted with osmotic minipumps filled with resveratrol $(0.1 \mu \mathrm{g} / \mathrm{d}$ or $0.2 \mu \mathrm{g} / \mathrm{d})$ or the SIRT1 antagonist EX-527 $(0.5 \mu \mathrm{g} / \mathrm{d}$ or $1.0 \mu \mathrm{g} / \mathrm{d})$ targeting the NAc for $14 \mathrm{~d}$ and tested on a battery of behavioral tasks on days 15-18, followed by tissue collection. SIRT1 catalytic assay shows increased SIRT1 deacetylase activity in the NAc of mice infused with resveratrol ( $n=7$ ) and decreased SIRT1 deacetylase activity in the NAc of mice infused with EX-527 $(n=6) . \boldsymbol{B}-\boldsymbol{H}$, Sustained intra-NAc infusion of resveratrol at $0.2 \mu \mathrm{g} / \mathrm{d}$ results in decreased time in the center of an open field $(n=8-9 ; \boldsymbol{B})$, decreases time in the open arms of an elevated-plus maze $(n=6-10 ; \boldsymbol{C})$, and decreased sucrose preference $(n=6-7 ; \boldsymbol{D})$ without changes in exploratory behaviors $(\boldsymbol{E}-\boldsymbol{H})$. I- $\mathbf{O}$, (Figure legend continues.) 

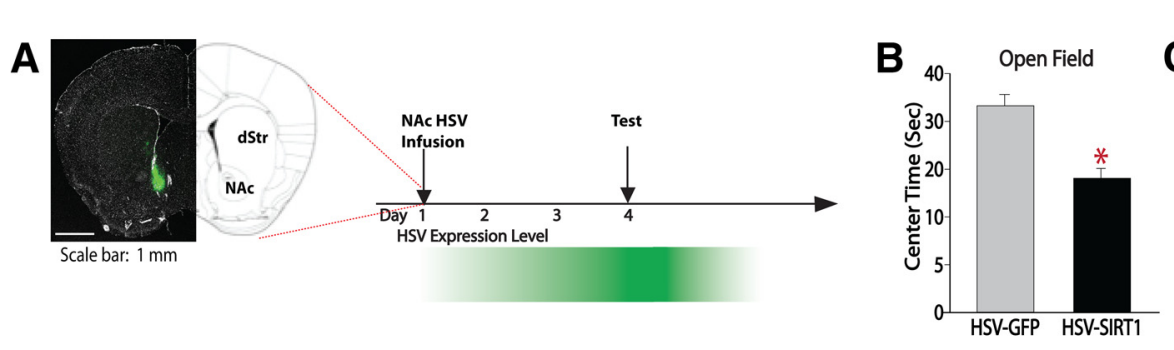

Baseline Behavior
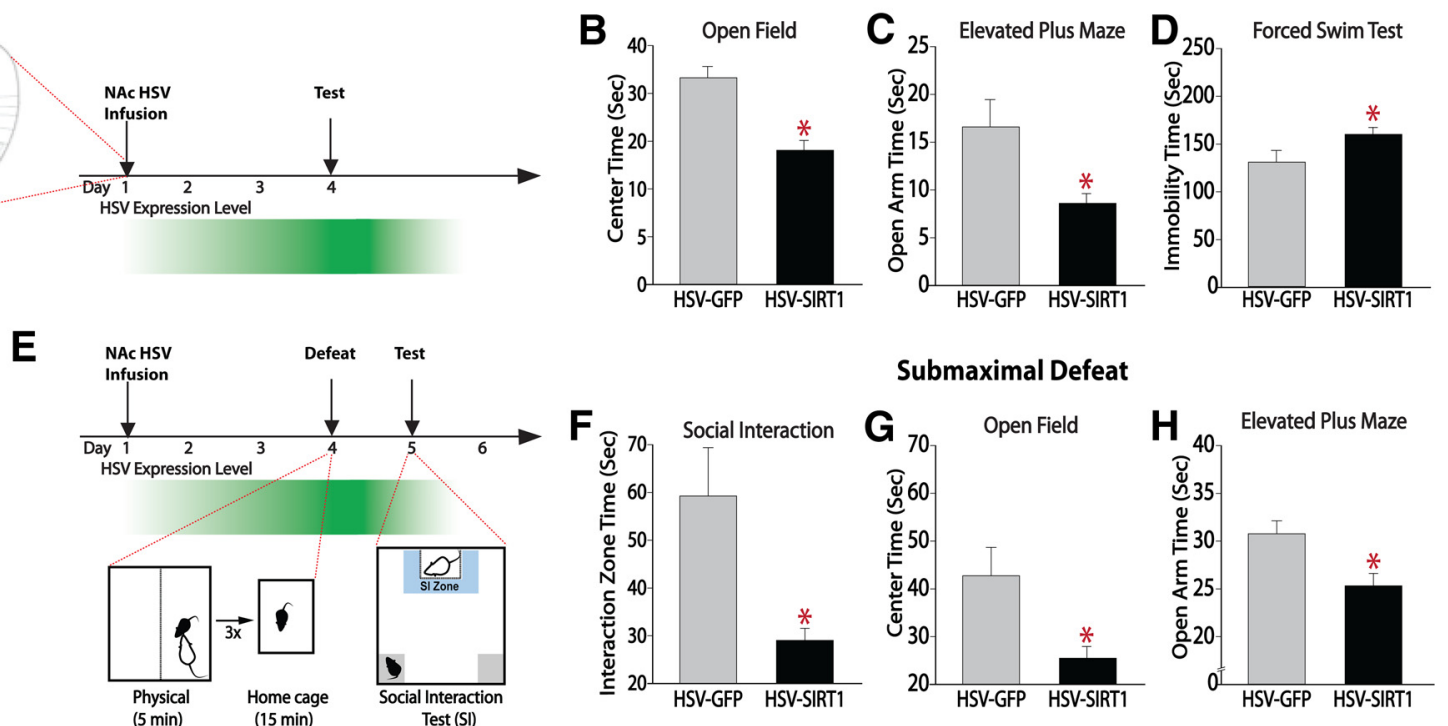

Submaximal Defeat
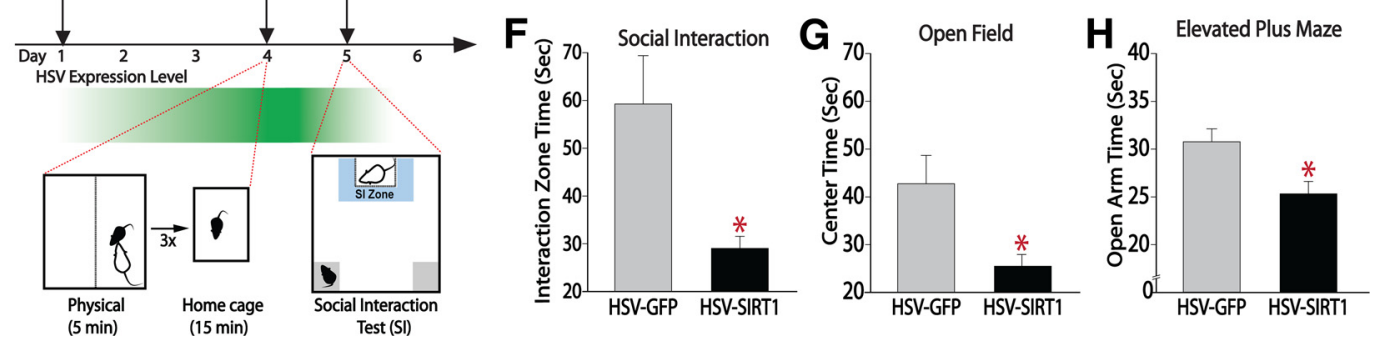

Figure 4. SIRT1 overexpression in the NAc promotes depressive- and anxiety-like behaviors. $A$, Schematic illustrating HSV targeting and expression profile in the NAc. HSV vectors begin to express $1 \mathrm{~d}$ after infusion and mediated increased expression until day 4, after which time expression dissipates, consistent with previous studies (Barrot et al., 2002). $\boldsymbol{B}-\boldsymbol{D}, 0$ verexpression of SIRT1 in the NAc increases depression- and anxiety-like behaviors, as measured by decreased time spent exploring the center of an open field $(n=7 ; \boldsymbol{B})$ and open arms of an elevated-plus maze $(n=7-10 ; \boldsymbol{C})$ and increase immobility time in the forced swim test $(n=9-10 ; \boldsymbol{D})$. $\boldsymbol{E}$, Schematic of expression profile of HSV and submaximal defeat procedure. $\boldsymbol{F}$-H, Submaximal defeat decreased social interaction $(n=9-13 ; \boldsymbol{F})$, time in center of an open field $(n=10 ; \boldsymbol{G})$, and time in the open arms of an elevated-plus maze $(n=10 ; \boldsymbol{H})$. ${ }^{*} p<0.05$. Data are represented as the mean \pm SEM.

ations in exploratory behaviors (Fig. $3 L-O$ ). In stress-naive mice, such infusions also increased the time spent in the center of an open field (Fig. 3I; $F_{(2,32)}=4.54, p=0.01$ ), with no changes seen in the elevated-plus maze (Fig. $3 J$ ). We then tested the ability of SIRT1 inhibition to block behavioral abnormalities observed after chronic social defeat stress (Fig. 3P). We found that intra-NAc infusions of EX-527 30 min before behavioral testing blocks defeat-induced increases in anxiety-like behaviors on the open field (Fig. 3Q; unpaired $t$ test, $t_{(12)}=2.39, p=0.03$ ) and elevatedplus maze (Fig. $3 R$; unpaired $t$ test, $t_{(12)}=2.18, p=0.04$ ) compared with vehicle. In addition, EX-527 infusions into NAc blocked the effects of social defeat stress on social avoidance behavior (Fig. 3S; unpaired $t$ test, $t_{(11)}=2.50, p=0.02$ ). These studies demonstrate that infusions of a SIRT1 inhibitor into the NAc attenuate depression- and anxiety-like behaviors.

\section{HSV-SIRT1 overexpression increases baseline anxiety-like and acute stress behaviors}

To complement these pharmacological data, we increased SIRT1 levels directly in the NAc neurons by injecting an HSV vector expressing SIRT1 as well as GFP (HSV-SIRT1) into this region of wildtype C57BL/6J male mice (Fig. 4A). Control mice were injected with an HSV vector that expresses GFP alone (Fig. 4A). Animals were examined $3 \mathrm{~d}$ after HSV injection in the open-field procedure, which revealed increased anxiety-like behavior, as indicated by decreased time spent exploring the center of the field (Fig. $4 B$; unpaired $t$ test, $\left.t_{(12)}=2.7, p=0.02\right)$. These effects were not associated with changes

\section{$\leftarrow$}

(Figure legend continued.) Sustained intra-NAc infusion of EX-527 at $0.5 \mu \mathrm{g} / \mathrm{d}$ results in increased center time on an open field $(n=13 ; \boldsymbol{l})$ and no changes in exploratory behaviors $(\boldsymbol{L}-\mathbf{0})$. P $\mathbf{P}$, Effects of EX-527 infusions on the development of stress-induced depression- and anxiety-like behaviors. EX-527 infusions block stress induced depression- and anxiety-like symptoms as reflected by increased social interaction time $(n=6-7 ; 5)$ and increased time in the center of an open field $(n=7 ; \boldsymbol{Q})$ and open arms of an elevated-plus maze $(n=6-8 ; \boldsymbol{R})$. $\# p<0.09,{ }^{*} p<0.05,{ }^{* *} p<0.01$. Data are represented as the mean \pm SEM. in other performance variables such as velocity and total distance traveled (data not shown). Similarly, mice expressing HSV-SIRT1 displayed a decrease in time spent exploring the open arm of the elevated-plus maze (Fig. $4 C$; unpaired $t$ test, $t_{(15)}=2.2, p=0.04$ ). In the forced swim test, increased SIRT1 levels in the NAc increased immobility time (Fig. $4 D$; unpaired $t$ test, $t_{(17)}=2.2, p=0.03$ ) typically interpreted as a prodepressive-like phenotype. These results suggest that SIRT1 increases baseline anxiety-like behavior and acute stress responses directly when overexpressed in the NAc of wild-type mice.

\section{SIRT1 overexpression in the NAc increases vulnerability to} stress-induced depression- and anxiety-like behaviors

We next subjected mice infused intra-NAc with HSV-GFP or HSV-SIRT1 to a submaximal defeat stress protocol, which consists of $35 \mathrm{~min}$ defeat episodes interspersed by $15 \mathrm{~min}$ rest periods $3 \mathrm{~d}$ after HSV surgery (Fig. 4E); this subthreshold social defeat protocol does not induce social avoidance in normal mice and is used to reveal potential prosusceptible effects of experimental manipulations (Krishnan et al., 2007, 2008). Social interaction testing conducted $24 \mathrm{~h}$ later revealed that mice expressing HSVSIRT1 exhibited decreased interaction with a social target, which represents a prodepression-like response compared with HSVGFP controls (Fig. 4F; unpaired $t$ test, $t_{(20)}=2.4, p=0.02$ ). In addition, mice expressing HSV-SIRT1 displayed an increase in anxiety-like behaviors when studied in an open field (Fig. $4 G$; unpaired $t$ test, $t_{(19)}=1.9, p=0.03$ ) or elevated-plus maze (Fig. $4 H$; unpaired $t$ test, $\left.t_{(21)}=1.6, p=0.05\right)$. No changes were observed in other performance variables. These results suggest that SIRT1 in the NAc promotes stress-induced depression- and anxiety-like behaviors.

\section{SIRT1 ablation in the NAc decreases depression- and anxiety-like behaviors}

In a complementary study, to determine whether SIRT1 knockdown decreases depression- and anxiety-like behavior, we in- 
A

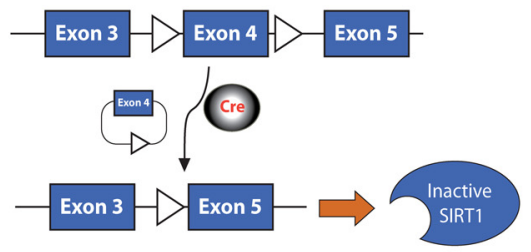

B

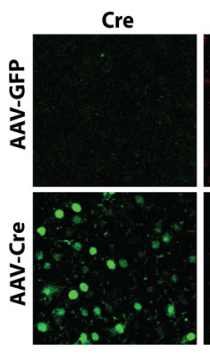

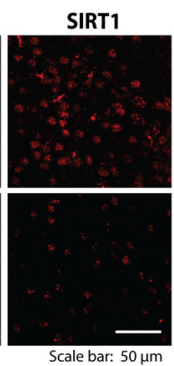
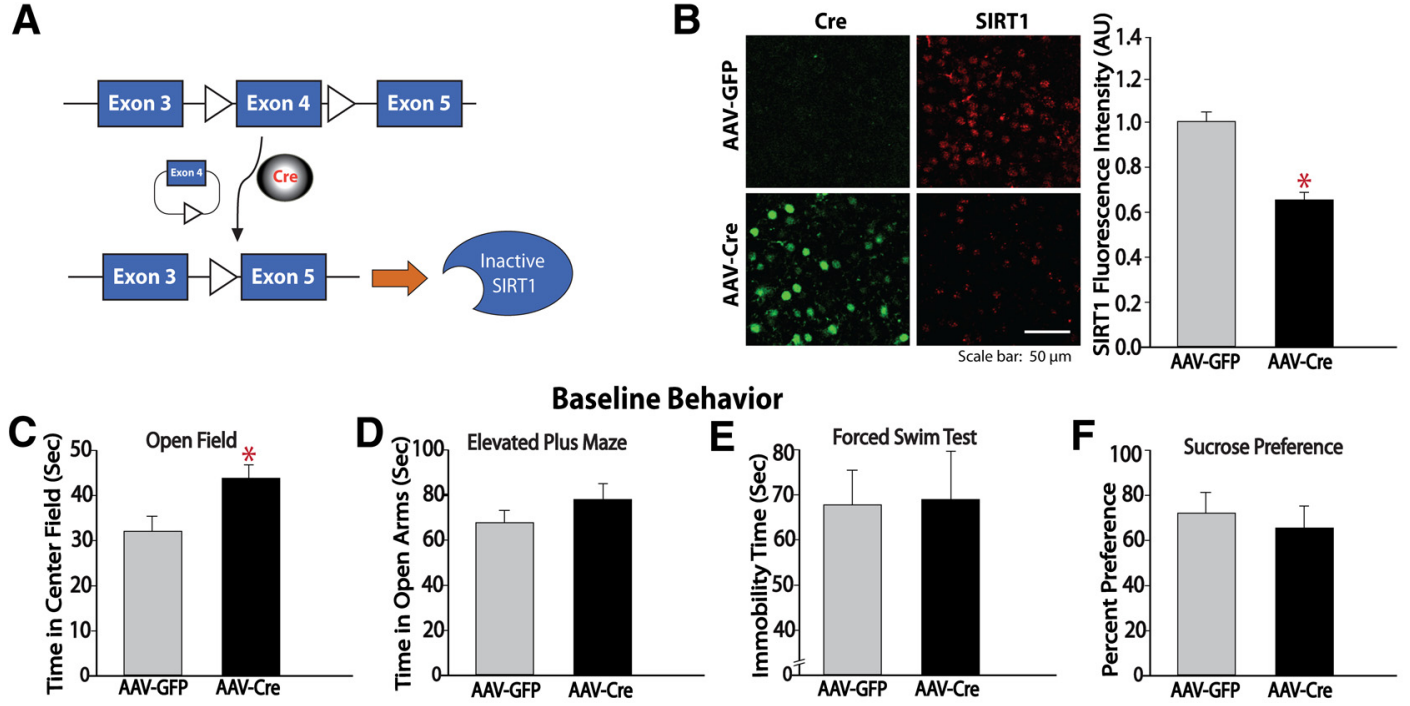

Submaximal Defeat
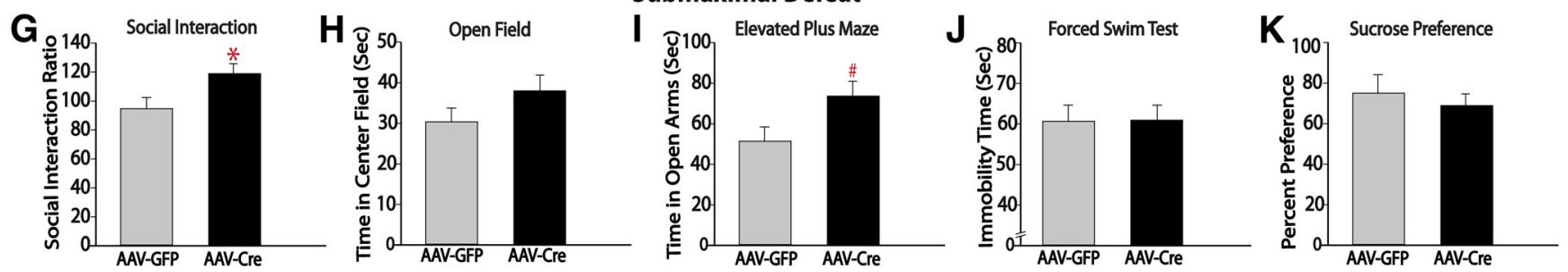

Figure 5. SIRT1 ablation in the NAc induces antidepressant- and anxiolytic-like responses. $\boldsymbol{A}$, Schematic representing the floxed exon 4 of the Sirt1 gene that, in the presence of Cre recombinase, is excised, resulting in nonfunctional SIRT1 protein. $\boldsymbol{B}$, Immunohistochemistry showing the knock-down of SIRT1 expression in the NAc of floxed Sirt1 mice injected intra-NAc with AAV-Cre $(n=5-6)$. C $-\boldsymbol{F}$, SIRT1 knock-down from NAc with AAV-Cre decreases basal anxiety-like behavior as reflected by an increase in center time of an open field $(n=$ $11-14 ; \boldsymbol{C}) . \mathbf{G}-\boldsymbol{K}$, SIRT1 knock-down from NAc also produces antidepressant like responses as reflected by an increase in social interaction time $(n=10 ; \boldsymbol{G})$. \#p $<0.09$, ${ }^{*} p<0.05$. Data are represented as the mean \pm SEM.

fused an AAV vector expressing Cre recombinase plus GFP or GFP alone specifically into NAc of mice homozygous for a loxP-flanked Sirt1 gene (Li et al., 2007). Eighteen days after AAV injection (when transgene expression is maximal), SIRT1 knockdown was confirmed by immunohistochemistry (Fig. 5B), which revealed a significant decrease in SIRT1 immunofluorescence intensity in the NAc of mice infused with AAV-Cre (unpaired $t$ test, $t_{(9)}=-2.7, p=0.02$ ). Using this approach, we observed that animals expressing AAV-Cre showed increased time spent in the center of an open field (Fig. $5 C$; unpaired $t$ test, $t_{(23)}=2.4, p=$ 0.02 ) indicative of a decrease in anxiety-like behavior. In addition, after defeat stress, mice with ablation of the Sirt1 gene in the NAc showed an antidepressant-like phenotype, as illustrated by an increase in social interaction time (Fig. 5G; unpaired $t$ test, $\left.t_{(18)}=2.3, p=0.03\right)$. These results suggest that decreasing SIRT1 levels in the NAc produces antidepressant- and anxiolytic-like effects.

SIRT1 regulation of depression- and anxiety-like behaviors is cell-type specific in the NAc

To better understand the mechanism by which increased SIRT1 function in the NAc promotes depression- and anxietylike behavioral responses, we overexpressed SIRT1 selectively in either of the two major neuronal cell types in the NAc, MSNs that express predominantly either the D1 or D2 dopamine receptor. We achieved this by generating HSV vectors that express SIRT1 (HSV-LS1L-SIRT1) or EYPF (HSV-LS1LEYPF) in a Cre-dependent manner and injected the vectors into the NAc of D1-Cre or D2-Cre mice (Fig. 6A, B). Immunostaining confirmed Cre-dependent overexpression of SIRT1 in the NAc of both Cre lines and significant increases of SIRT1 expression levels at the injection sites of HSV-LS1LSIRT1 (Fig. $6 B$; unpaired $t$ test, $t_{(8)}=9.5, p=0.00001$ ). We then performed a series of behavioral studies to measure depression- and anxiety-like behaviors in D1-Cre or D2-Cre mice expressing HSV-LS1L-SIRT1 or HSV-LS1L-EYPF. In D1-Cre mice infused with HSV-LS1L-SIRT1, we observed a significant decrease in time spent in the center of an open field (Fig. 6C; unpaired $t$ test, $t_{(17)}=-2.6, p=0.02$ ), increased immobility time (Fig. $6 E$; unpaired $t$ test, $t_{(17)}=2.8, p=0.01$ ) in the forced swim test, and decreased sucrose preference (Fig. $6 F$; unpaired $t$ test, $\left.t_{(9)}=-2.4, p=0.04\right)$ relative to HSVLS1L-EYPF controls. In addition, after submaximal defeat stress, we observed an increase in anxiety-like behavior in mice overexpressing SIRT1 selectively in D1 MSNs, as reflected by a decrease in time spent exploring the center of an open field (Fig. $6 H$; unpaired $t$ test, $t_{(10)}=-2.6, p=0.02$ ) and strong trend toward decreased time spent exploring the open arms of an elevated-plus maze (Fig. $6 I$; unpaired $t$ test, $t_{(9)}=$ $-2.1, p=0.06)$. Moreover, we observed a strong trend toward an increase in depression-like behaviors, as reflected by a decrease in social interaction time (Fig. 6G; unpaired $t$ test, $\left.t_{(10)}=-2.1, p=0.06\right)$. In contrast, we did not observe any changes in behavioral responses when SIRT1 was overexpressed selectively in D2 MSNs. These results suggest that 
A

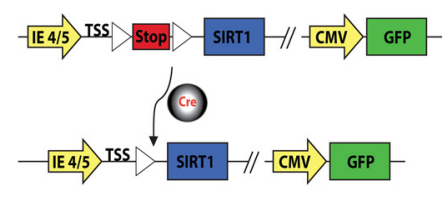

B

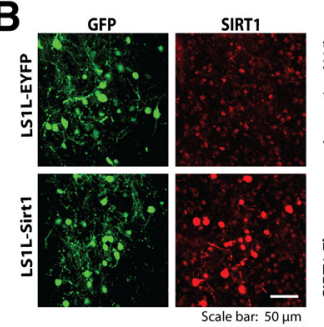

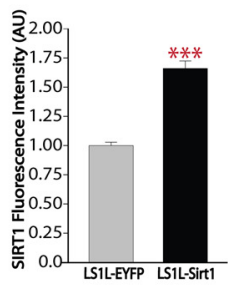
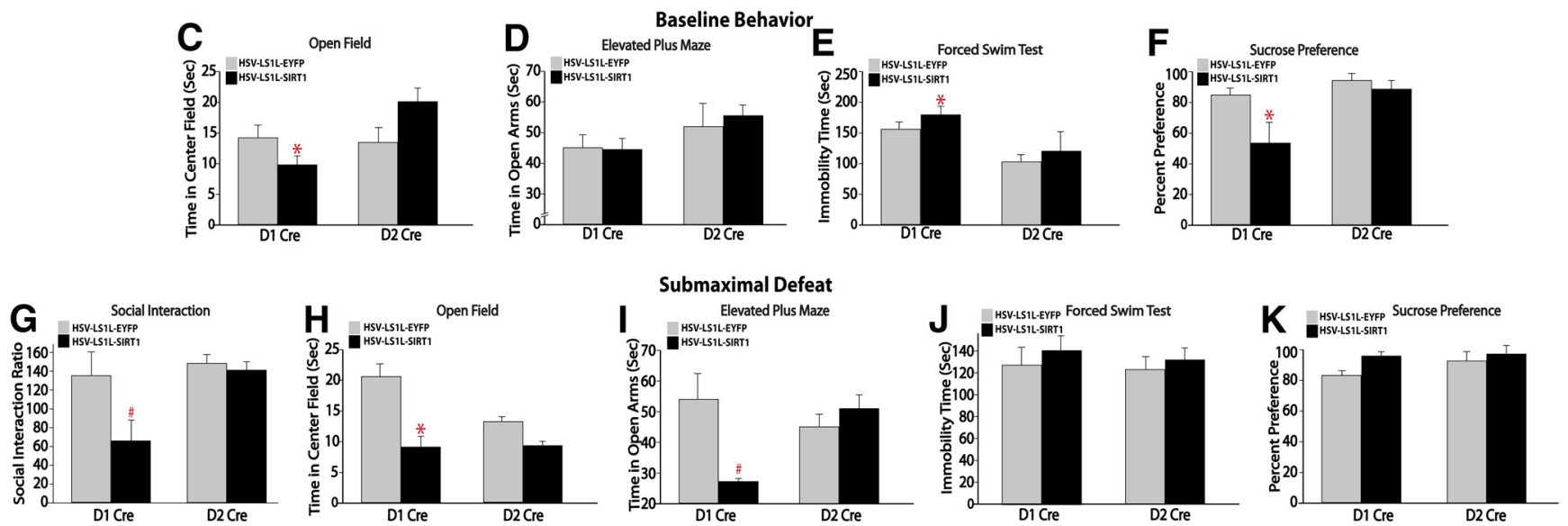

Figure 6. SIRT1 mediates depression- and anxiety-like behaviors via cell-type-specific actions. A, Map of conditional Stop ${ }^{\mathrm{f} / \text { /f }}$ HSV vectors to overexpress SIRT1 selectively in D1 or D2 MSNs. LoxP surrounds the stop cassette between the IE 4/5 promoter-driven TSS and sequence encoding SIRT1, followed by a constitutive CMV promoter-driven GFP. $\boldsymbol{B}$, Cells that express Cre recombinase (green) delete the stop sequence, allowing the IE 4/5 promoter to drive ectopic expression of SIRT1 (red; $n=5$ ). $C-F$, Cell-type-specific overexpression of SIRT1 in D1 MSNs increases baseline depression- and anxiety-like behaviors as measured by decreased time spent in the center of an open field $(n=9-10 ; \boldsymbol{C})$, increased immobility time in the forced swim test $(n=9-10 ; \boldsymbol{E})$, and decreased sucrose preference $(n=5-6 ; \boldsymbol{F}) . \mathbf{G}-\boldsymbol{K}$, Strong trend toward decreased social interaction ratio $(\boldsymbol{G})$ after submaximal defeat $(n=6)$ and decreased time on open arms of elevated-plus maze $(\boldsymbol{I})$ in addition to significant decrease in center time of an open field $(\boldsymbol{H})$ in mice selectively overexpressing SIRT1 in D1 MSNs. In contrast, SIRT1 overexpression had no effect in D2 MSNs. \#p $<0.09$, ${ }^{*} p<0.05,{ }^{* * *} p<0.001$ Data are represented as the mean \pm SEM.

SIRT1 produces its prodepression and anxiety-like effects via actions in D1 MSNs.

\section{Discussion}

\section{Chronic stress induces Sirt1 expression in the NAc of} susceptible mice

Our results demonstrate that SIRT1, a class III HDAC, regulates depression- and anxiety-like behaviors via actions in the NAc. We show that chronic social defeat stress stably induces SIRT1 expression in the NAc, characterized by elevations of SIRT1 $48 \mathrm{~h}$ and $10 \mathrm{~d}$ after exposure to the last defeat episode. Elevations in Sirt1 mRNA levels were specific to chronic stress because an acute social defeat episode did not alter Sirt1 expression. Moreover, we revealed that the increased Sirt1 expression likely reflects transcriptional activation because it accompanies an active histone modification (H3K4me3) at the TSS of the Sirt1 promoter. Interestingly, whereas we observed increases in Sirt1 mRNA levels in the NAc, there was a concomitant decline in Sirt1 expression in the hippocampus at the $48 \mathrm{~h}$ time point. This opposite expression of Sirt 1 in the NAc versus the hippocampus is consistent with other studies showing opposing regulation of several other signaling pathways (e.g., BDNF-TrkB signaling, CREB, and HDAC5) between these two brain regions in animal models of depression (Nestler et al., 2002; Tsankova et al., 2006; Renthal et al., 2007).

Several studies have shown decreased activity in the NAc, inferred from brain-imaging findings, of patients suffering from MDD (Drevets et al., 1992; Mayberg et al., 2000), which is thought to correspond to a decreased ability to experience pleasure or reward. We hypothesize that SIRT1, acting as a transcrip- tional repressor, contributes to the observed decrease in the NAc activity observed in these patients. Previous ChIP-seq and RNA-seq data have established SIRT1's role as a transcriptional repressor in the NAc (Ferguson et al., 2015). Further studies are now needed to identify the target genes for SIRT1 that mediate its functional effects.

\section{Upregulation of SIRT1 in the NAc increases susceptibility}

We also present compelling evidence that the lasting induction of SIRT1 expression in the NAc after chronic social defeat stress contributes to the persistent behavioral abnormalities observed under these conditions. We show that altering SIRT1 activity using a pharmacological or genetic approach controls depression- and anxietylike behaviors bidirectionally. We demonstrated that infusion of the nonspecific sirtuin agonist resveratrol promotes depression- and anxiety-like behavioral deficits, whereas inhibition of SIRT1 with a more selective antagonist, EX-527 (Gertz et al., 2013), induces antidepressant- and anxiolytic-like responses. We did not observe changes in baseline behaviors when resveratrol was injected systemically for 14 days, which is consistent with an earlier study (Liu et al., 2014). However, another study showed antidepressant-like effects of systemic resveratrol (Hurley et al., 2014). These conflicting results may be due to differences in dose of resveratrol, duration of administration, and rodent model used.

To complement the pharmacological approach, we used overexpressed SIRT1 in the NAc using HSV vectors or, conversely, reduced SIRT1 levels using AAV-Cre in floxed Sirt1 mice (Li et al., 2007). We show that overexpression of SIRT1 in the NAc increases baseline depression- and anxiety-like behaviors and renders mice more susceptible to submaximal social defeat. In contrast, local knock-down 
of SIRT1 in the NAc produced antidepressant- and anxiolytic-like effects. In addition, we targeted the overexpression of SIRT1 to selective cell types in the NAc, D1 MSNs or D2-MSNs, and show that increased depression- and anxiety-like behaviors are driven specifically by D1 MSNs, with no changes observed when SIRT1 was overexpressed in D2 MSNs.

Consistent with the present findings, a recent study showed that global decreases of SIRT1 using brain-specific SIRT1 knockout mice, which have the catalytic domain of SIRT1 (exon 4) deleted throughout the nervous system (Cohen et al., 2009), also results in reduced baseline anxiety-like behaviors and increased resilience to social defeat stress (Libert et al., 2011). In contrast, SIRT1-overexpressing mice (Bordone et al., 2007), which have twofold higher SIRT1 levels as control mice, displayed increased susceptibility to anxiety- and depression-related responses (Libert et al., 2011). In addition, a chronic variable stress model of depression in rats showed a correspondence between increased sirtuin activity and prodepressive- and anxiety-like behaviors, results consistent with our findings (Ferland et al., 2013).

\section{Cell-type-specific actions of SIRT1 modulate depression- and anxiety-like behaviors}

What is not understood is how SIRT1 influences depression- and anxiety-like behaviors in a cell- and circuit-specific manner. The present study addresses this important question for the first time and demonstrates a cell-type-specific role of SIRT1 in the regulation of these behavioral abnormalities in the NAc. We show that the cell-type-specific overexpression of SIRT1 in D1, but not in D2, MSNs promotes depressive- and anxiety-like behaviors and hypothesize that SIRT1 acts as a transcriptional repressor in the D1 pathway, thereby decreasing the ability to experience reward. It is currently believed that activation of D1-MSNs produces positive rewarding behavior, whereas activation of D2 MSNs leads to aversive behaviors (Maia and Frank, 2011; Freeze et al., 2013). Recent optogenetic studies support this notion (Lobo et al., 2010; Koo et al., 2014; Francis et al., 2015). We thus hypothesize that increases in SIRT1-mediated transcriptional repression leads to decreases in the activity of the D1 pathway. For example, after restraint stress, anhedonia-like behavior is mediated by decreases in excitatory synaptic strength of NAc D1 MSNs, with no changes in D2 MSNs (Lim et al., 2012). In addition, after chronic social defeat stress, susceptible mice have decreased excitatory inputs into D1, but not D2, MSNs and chronic chemogenetic attenuation of D1 MSNs induced depressive-like behaviors in mice that were previously resilient (Francis et al., 2015).

Previously, we reported that SIRT1 overexpression in the NAc, which suppresses natural reward in the present study, enhances cocaine and morphine reward (Ferguson et al., 2013). The explanation for this paradox is not known. One possibility is that SIRT1 exerts different effects in D1 versus D2 MSNs, as noted above. Moreover, a review of the literature shows a highly complex relationship between the effect of molecular manipulations in the NAc on stress- versus addiction-related outcomes: a given manipulation that enhances drug reward can promote, reduce, or have no effect on depression- and anxiety-like behaviors and vice versa (Russo and Nestler, 2013). Further work is needed to address this complexity.

\section{BDNF pathway is a putative target of SIRT1 signaling in the NAc}

SIRT1 may regulate depressive-like symptoms through the BDNF signaling pathway. Direct evidence for a SIRT1-BDNF interaction comes from a recent study (Ferguson et al., 2013) demonstrating that SIRT1 overexpression increases Bdnf expression in the NAc and a ChIP-seq analysis revealing that the $B d n f$ gene is a downstream transcriptional target of SIRT1 (Ferguson et al., 2015). Moreover, SIRT1 has been found to act through a disinhibitory pathway to regulate the expression of BDNF by inhibiting miR-134, which downregulates BDNF levels (Gao et al., 2010). Several studies have established that chronic social defeat stress increases BDNF signaling in the VTA-NAc mesolimbic pathway, thereby promoting susceptibility to stress-induced behavioral deficits (Berton et al., 2006; Krishnan et al., 2007; Walsh et al., 2014; Koo et al., 2016). Interestingly, postmortem tissue from depressed patients shows elevated levels of BDNF in the NAc (Krishnan et al., 2007). Together, these studies suggest that SIRT1 is a key regulator of BDNF signaling, which in turn is linked to depression (Berton et al., 2006; Krishnan et al., 2007). Additional studies will be required to confirm conclusively the SIRT1-BDNF signaling pathway in our model of depression.

\section{Translational importance of Sirt1 regulation in human depression}

A recent publication by the CONVERGE Consortium identified a reproducible association of the SIRT1 locus in Han Chinese with MDD (CONVERGE Consortium, 2015). This is the first report of a genetic linkage with MDD that achieves genome-wide significance. Therefore, our results that SIRT1 functions in the NAc to regulate depression- and anxiety-like behaviors are of significant translational importance and reveal a novel path forward for the development of therapeutic targets for depression. Additional support for the translational significance of our findings comes from Libert et al. (2011), who identified SNPs (rs10997870) in the SIRT1 gene associated with risk of anxiety (panic disorder and social phobias) in humans. These findings were also replicated using samples from the Virginia Adult Twin Study of Psychiatric and Substance Use Disorders (VATSPSUD), which consists of 9000 adult Caucasian twins (Kendler et al., 2001). An independent study of Japanese subjects also found a significant association between another SIRT1 SNP (rs10997875) and MDD (Kishi et al., 2010). Importantly, the finding that chronic social defeat stress increases SIRT1 levels in the NAc and that two of the most frequent genetic variations in the $\mathrm{N}$ terminus (S14P and P37L) increase SIRT1 protein activity (Libert et al., 2011) support the translational relevance of the social defeat procedure and its construct validity. Together, these results suggest that SIRT1 plays an essential role in regulating depression- and anxiety-related behaviors and introduces a novel signaling pathway for the development of innovative antidepressants to treat MDD.

\section{References}

Asher G, Gatfield D, Stratmann M, Reinke H, Dibner C, Kreppel F, Mostoslavsky R, Alt FW, Schibler U (2008) SIRT1 regulates circadian clock gene expression through PER2 deacetylation. Cell 134:317-328. CrossRef Medline

Bagot RC, Cates HM, Purushothaman I, Lorsch ZS, Walker DM, Wang J, Huang X, Schlüter OM, Maze I, Peña CJ, Heller EA, Issler O, Wang M, Song WM, Stein JL, Liu X, Doyle MA, Scobie KN, Sun HS, Neve RL, et al. (2016) Circuit-wide transcriptional profiling reveals brain regionspecific gene networks regulating depression susceptibility. Neuron 90: 969-983. CrossRef Medline

Barrot M, Olivier JD, Perrotti LI, DiLeone RJ, Berton O, Eisch AJ, Impey S, Storm DR, Neve RL, Yin JC, Zachariou V, Nestler EJ (2002) CREB activity in the nucleus accumbens shell controls gating of behavioral responses to emotional stimuli. Proc Natl Acad Sci USA 99:11435-11440.

Berton O, McClung CA, Dileone RJ, Krishnan V, Renthal W, Russo SJ, Graham D, Tsankova NM, Bolanos CA, Rios M, Monteggia LM, Self DW, Nestler EJ (2006) Essential role of BDNF in the mesolimbic dopamine pathway in social defeat stress. Science 311:864-868. CrossRef Medline 
Bordone L, Cohen D, Robinson A, Motta MC, van Veen E, Czopik A, Steele AD, Crowe H, Marmor S, Luo J, Gu W, Guarente L (2007) SIRT1 transgenic mice show phenotypes resembling calorie restriction. Aging Cell 6:759-767. CrossRef Medline

Chang HC, Guarente L (2013) SIRT1 mediates central circadian control in the SCN by a mechanism that decays with aging. Cell 153:1448-1460. CrossRef Medline

Cohen DE, Supinski AM, Bonkowski MS, Donmez G, Guarente LP (2009) Neuronal SIRT1 regulates endocrine and behavioral responses to calorie restriction. Genes Dev 23:2812-2817. CrossRef Medline

CONVERGE Consortium (2015) Sparse whole-genome sequencing identifies two loci for major depressive disorder. Nature 523:588-591. CrossRef Medline

Covington HE 3rd, Maze I, LaPlant QC, Vialou VF, Ohnishi YN, Berton O, Fass DM, Renthal W, Rush AJ 3rd, Wu EY, Ghose S, Krishnan V, Russo SJ, Tamminga C, Haggarty SJ, Nestler EJ (2009) Antidepressant actions of histone deacetylase inhibitors. J Neurosci 29:11451-11460. CrossRef Medline

Covington HE 3rd, Vialou V, Nestler EJ (2010) From synapse to nucleus: novel targets for treating depression. Neuropharmacology 58:683-693. CrossRef Medline

Dias C, Feng J, Sun H, Shao NY, Mazei-Robison MS, Damez-Werno D, Scobie K, Bagot R, LaBonté B, Ribeiro E, Liu X, Kennedy P, Vialou V, Ferguson D, Peña C, Calipari ES, Koo JW, Mouzon E, Ghose S, Tamminga $C$, et al. (2014) $\beta$-Catenin mediates stress resilience through Dicer1/microRNA regulation. Nature 516:51-55. Medline

Drevets WC, Videen TO, Price JL, Preskorn SH, Carmichael ST, Raichle ME (1992) A functional anatomical study of unipolar depression. J Neurosci 12:3628-3641. Medline

Ferguson D, Koo JW, Feng J, Heller E, Rabkin J, Heshmati M, Renthal W, Neve R, Liu X, Shao N, Sartorelli V, Shen L, Nestler EJ (2013) Essential role of SIRT1 signaling in the nucleus accumbens in cocaine and morphine action. J Neurosci 33:16088-16098. CrossRef Medline

Ferguson D, Shao N, Heller E, Feng J, Neve R, Kim HD, Call T, Magazu S, Shen L, Nestler EJ (2015) SIRT1-FOXO3a regulate cocaine actions in the nucleus accumbens. J Neurosci 35:3100-3111. CrossRef Medline

Ferland CL, Hawley WR, Puckett RE, Wineberg K, Lubin FD, Dohanich GP, Schrader LA (2013) Sirtuin activity in dentate gyrus contributes to chronic stress-induced behavior and extracellular signal-regulated protein kinases 1 and 2 cascade changes in the hippocampus. Biol Psychiatry 74:927-935. CrossRef Medline

Francis TC, Chandra R, Friend DM, Finkel E, Dayrit G, Miranda J, Brooks JM, Iñiguez SD, O’Donnell P, Kravitz A, Lobo MK (2015) Nucleus accumbens medium spiny neuron subtypes mediate depression-related outcomes to social defeat stress. Biol Psychiatry 77:212-222. CrossRef Medline

Freeze BS, Kravitz AV, Hammack N, Berke JD, Kreitzer AC (2013) Control of basal ganglia output by direct and indirect pathway projection neurons. J Neurosci 33:18531-18539. CrossRef Medline

Gao J, Wang WY, Mao YW, Gräff J, Guan JS, Pan L, Mak G, Kim D, Su SC, Tsai LH (2010) A novel pathway regulates memory and plasticity via SIRT1 and miR-134. Nature 466:1105-1109. CrossRef Medline

Gerfen CR, Paletzki R, Heintz N (2013) GENSAT BAC cre-recombinase driver lines to study the functional organization of cerebral cortical and basal ganglia circuits. Neuron 80:1368-1383. CrossRef Medline

Gertz M, Fischer F, Nguyen GT, Lakshminarasimhan M, Schutkowski M, Weyand M, Steegborn C (2013) Ex-527 inhibits Sirtuins by exploiting their unique NAD+-dependent deacetylation mechanism. Proc Natl Acad Sci U S A 110:E2772-E2781. CrossRef Medline

Gong S, Doughty M, Harbaugh CR, Cummins A, Hatten ME, Heintz N, Gerfen CR (2007) Targeting Cre recombinase to specific neuron populations with bacterial artificial chromosome constructs. J Neurosci 27: 9817-9823. CrossRef Medline

Grueter BA, Robison AJ, Neve RL, Nestler EJ, Malenka RC (2013) ÆFosB differentially modulates nucleus accumbens direct and indirect pathway function. Proc Natl Acad Sci U S A 110:1923-1928. CrossRef Medline

Holmes A, Wellman CL (2009) Stress-induced prefrontal reorganization and executive dysfunction in rodents. Neurosci Biobehav Rev 33: 773-783. CrossRef Medline

Hurley LL, Akinfiresoye L, Kalejaiye O, Tizabi Y (2014) Antidepressant effects of resveratrol in an animal model of depression. Behav Brain Res 268:1-7. CrossRef Medline

Kendler KS, Gardner CO, Prescott CA (2001) Panic syndromes in a population-based sample of male and female twins. Psychol Med 31: 989-1000. Medline

Kishi T, Yoshimura R, Kitajima T, Okochi T, Okumura T, Tsunoka T, Yamanouchi Y, Kinoshita Y, Kawashima K, Fukuo Y, Naitoh H, UmeneNakano W, Inada T, Nakamura J, Ozaki N, Iwata N (2010) SIRT1 gene is associated with major depressive disorder in the Japanese population. J Affect Disord 126:167-173. CrossRef Medline

Koo JW, Lobo MK, Chaudhury D, Labonté B, Friedman A, Heller E, Peña CJ, Han MH, Nestler EJ (2014) Loss of BDNF signaling in D1R-expressing NAc neurons enhances morphine reward by reducing GABA inhibition. Neuropsychopharmacology 39:2646-2653. CrossRef Medline

Koo JW, Labonté B, Engmann O, Calipari ES, Jaurez B, Lorsch Z, Walsh JJ, Friedman AK, Yorgason JT, Han MH, Nestler EJ (2016) Essential role of mesolimbic brain-derived neurotrophic factor in chronic social stressinduced depressive behaviors. Biol Psychiatry. In press. CrossRef Medline Krishnan V, Nestler EJ (2008) The molecular neurobiology of depression. Nature 455:894-902. CrossRef Medline

Krishnan V, Nestler EJ (2011) Animal models of depression: molecular perspectives. Curr Top Behav Neurosci 7:121-147. CrossRef Medline

Krishnan V, Han MH, Graham DL, Berton O, Renthal W, Russo SJ, Laplant Q, Graham A, Lutter M, Lagace DC, Ghose S, Reister R, Tannous P, Green TA, Neve RL, Chakravarty S, Kumar A, Eisch AJ, Self DW, Lee FS, et al. (2007) Molecular adaptations underlying susceptibility and resistance to social defeat in brain reward regions. Cell 131:391-404. CrossRef Medline

Krishnan V, Han MH, Mazei-Robison M, Iñiguez SD, Ables JL, Vialou V, Berton O, Ghose S, Covington HE 3rd, Wiley MD, Henderson RP, Neve RL, Eisch AJ, Tamminga CA, Russo SJ, Bolaños CA, Nestler EJ (2008) AKT signaling within the ventral tegmental area regulates cellular and behavioral responses to stressful stimuli. Biol Psychiatry 64:691-700. CrossRef Medline

Kwon HS, Ott M (2008) The ups and downs of SIRT1. Trends Biochem Sci 33:517-525. CrossRef Medline

Lee IH, Cao L, Mostoslavsky R, Lombard DB, Liu J, Bruns NE, Tsokos M, Alt FW, Finkel T (2008) A role for the NAD-dependent deacetylase Sirt1 in the regulation of autophagy. Proc Natl Acad Sci U S A 105:3374-3379. CrossRef Medline

Li H, Rajendran GK, Liu N, Ware C, Rubin BP, Gu Y (2007) SirT1 modulates the estrogen-insulin-like growth factor-1 signaling for postnatal development of mammary gland in mice. Breast Cancer Res 9:R1. CrossRef Medline

Libert S, Pointer K, Bell EL, Das A, Cohen DE, Asara JM, Kapur K, Bergmann S, Preisig M, Otowa T, Kendler KS, Chen X, Hettema JM, van den Oord EJ, Rubio JP, Guarente L (2011) SIRT1 activates MAO-A in the brain to mediate anxiety and exploratory drive. Cell 147:1459-1472. CrossRef Medline

Lim BK, Huang KW, Grueter BA, Rothwell PE, Malenka RC (2012) Anhedonia requires MC4R-mediated synaptic adaptations in nucleus accumbens. Nature 487:183-189. CrossRef Medline

Liu D, Xie K, Yang X, Gu J, Ge L, Wang X, Wang Z (2014) Resveratrol reverses the effects of chronic unpredictable mild stress on behavior, serum corticosterone levels and BDNF expression in rats. Behav Brain Res 264:9-16. CrossRef Medline

Livak KJ, Schmittgen TD (2001) Analysis of relative gene expression data using real-time quantitative PCR and the 2(-Delta Delta $\mathrm{C}(\mathrm{T})$ ) Method. Methods 25:402-408. CrossRef Medline

Lobo MK, Covington HE 3rd, Chaudhury D, Friedman AK, Sun H, DamezWerno D, Dietz DM, Zaman S, Koo JW, Kennedy PJ, Mouzon E, Mogri M, Neve RL, Deisseroth K, Han MH, Nestler EJ (2010) Cell type specific loss of BDNF signaling mimics optogenetic control of cocaine reward. Science 330:385-390. CrossRef Medline

Maia TV, Frank MJ (2011) From reinforcement learning models to psychiatric and neurological disorders. Nat Neurosci 14:154-162. CrossRef Medline

Mayberg HS, Brannan SK, Tekell JL, Silva JA, Mahurin RK, McGinnis S, Jerabek PA (2000) Regional metabolic effects of fluoxetine in major depression: serial changes and relationship to clinical response. Biol Psychiatry 48:830-843. CrossRef Medline

Michán S, Li Y, Chou MM, Parrella E, Ge H, Long JM, Allard JS, Lewis K, Miller M, Xu W, Mervis RF, Chen J, Guerin KI, Smith LE, McBurney MW, Sinclair DA, Baudry M, de Cabo R, Longo VD (2010) SIRT1 is essential for normal cognitive function and synaptic plasticity. J Neurosci 30:9695-9707. CrossRef Medline 
Nakahata Y, Sahar S, Astarita G, Kaluzova M, Sassone-Corsi P (2009) Circadian control of the NAD+ salvage pathway by CLOCK-SIRT1. Science 324:654-657. CrossRef Medline

Nestler EJ, Barrot M, DiLeone RJ, Eisch AJ, Gold SJ, Monteggia LM (2002) Neurobiology of depression. Neuron 34:13-25. CrossRef Medline

Ramadori G, Coppari R (2011) Does hypothalamic SIRT1 regulate aging? Aging 3:325-328. CrossRef Medline

Ramadori G, Fujikawa T, Anderson J, Berglund ED, Frazao R, Michán S, Vianna CR, Sinclair DA, Elias CF, Coppari R (2011) SIRT1 deacetylase in SF1 neurons protects against metabolic imbalance. Cell Metab 14: 301-312. CrossRef Medline

Renthal W, Maze I, Krishnan V, Covington HE 3rd, Xiao G, Kumar A, Russo SJ, Graham A, Tsankova N, Kippin TE, Kerstetter KA, Neve RL, Haggarty SJ, McKinsey TA, Bassel-Duby R, Olson EN, Nestler EJ (2007) Histone deacetylase 5 epigenetically controls behavioral adaptations to chronic emotional stimuli. Neuron 56:517-529. CrossRef Medline

Renthal W, Kumar A, Xiao G, Wilkinson M, Covington HE 3rd, Maze I, Sikder D, Robison AJ, LaPlant Q, Dietz DM, Russo SJ, Vialou V, Chakravarty S, Kodadek TJ, Stack A, Kabbaj M, Nestler EJ (2009) Genomewide analysis of chromatin regulation by cocaine reveals a role for sirtuins. Neuron 62:335-348. CrossRef Medline

Russo SJ, Nestler EJ (2013) The brain reward circuitry in mood disorders. Nat Rev Neurosci 14:609-625. CrossRef Medline

Sassone-Corsi P (2012) Minireview: NAD+, a circadian metabolite with an epigenetic twist. Endocrinology 153:1-5. CrossRef Medline

Sesack SR, Grace AA (2010) Cortico-Basal Ganglia reward network: microcircuitry. Neuropsychopharmacology 35:27-47. CrossRef Medline
Sinclair DA, Guarente L (2014) Small-molecule allosteric activators of sirtuins. Annu Rev Pharmacol Toxicol 54:363-380. CrossRef Medline

Tonkin J, Villarroya F, Puri PL, Vinciguerra M (2012) SIRT1 signaling as potential modulator of skeletal muscle diseases. Curr Opin Pharmacol 12:372-376. CrossRef Medline

Tremblay LK, Naranjo CA, Graham SJ, Herrmann N, Mayberg HS, Hevenor S, Busto UE (2005) Functional neuroanatomical substrates of altered reward processing in major depressive disorder revealed by a dopaminergic probe. Arch Gen Psychiatry 62:1228-1236. CrossRef Medline

Tsankova NM, Berton O, Renthal W, Kumar A, Neve RL, Nestler EJ (2006) Sustained hippocampal chromatin regulation in a mouse model of depression and antidepressant action. Nat Neurosci 9:519-525. CrossRef Medline

Vaquero A, Sternglanz R, Reinberg D (2007) NAD+-dependent deacetylation of H4 lysine 16 by class III HDACs. Oncogene 26:5505-5520. CrossRef Medline

Walsh JJ, Friedman AK, Sun H, Heller EA, Ku SM, Juarez B, Burnham VL, Mazei-Robison MS, Ferguson D, Golden SA, Koo JW, Chaudhury D, Christoffel DJ, Pomeranz L, Friedman JM, Russo SJ, Nestler EJ, Han MH (2014) Stress gates neural activation of BDNF in the mesolimbic reward pathway. Nat Neurosci 17:27-29. CrossRef Medline

Wilkinson MB, Xiao G, Kumar A, LaPlant Q, Renthal W, Sikder D, Kodadek TJ, Nestler EJ (2009) Imipramine treatment and resiliency exhibit similar chromatin regulation in the mouse nucleus accumbens in depression models. J Neurosci 29:7820-7832. CrossRef Medline

Yang Y, Fu W, Chen J, Olashaw N, Zhang X, Nicosia SV, Bhalla K, Bai W (2007) SIRT1 sumoylation regulates its deacetylase activity and cellular response to genotoxic stress. Nat Cell Biol 9:1253-1262. CrossRef Medline 